\title{
The Grand Narrative of the Mukhomor
}

\author{
“Communist Dunaev" as a Mushroom Eater in Mifogennaia Liubov' Kast: \\ Understanding the Ethnobotanical History of the Younger Group of Russian \\ Conceptualists
}

\author{
Dennis Ioffe \\ Department of Slavic Languages \& Cultures, Faculty of Humanities, \\ The University of Amsterdam, Amsterdam, The Netherlands \\ Department of Languages and Cultures (Slavic \& East-European), \\ The Faculty of Arts, Ghent University, Ghent, Belgium \\ D.Ioffe@uva.nl
}

\begin{abstract}
This article addresses the complex role of mushrooms, particularly that of the fly agaric (Amanita muscaria) [Russian: Mukhomor], in the art of Moscow conceptualism in a broad setting. This paper explores the mythopoetic theme of mushroom-induced beliefs, which influenced the Moscow conceptualists, and employs background historical scholarship by R.G. Wasson, V.N. Toporov, T.J. Elizarenkova, and others. Aside from the mushrooms per se that were particularly important for Moscow conceptualism, this article also mentions various ethno-botanical entheogens (i.e. biochemical substances such as plants or drugs ingested in order to undergo certain spiritual experience, or "generating the divine within"). Apart from analyzing the ethnobotanical historical background of manifesting hallucinogenic mushrooms on the Russian soil (including Siberia), this article focuses on Pavel Peppershtein's novel Mifogennaia Liubov' Kast (The Mythogenic Love of the Castes), which was co-authored with Sergey Anufriev. As the narrative of the novel unfolds, its main character, the Communist Partorg (Party Organizer) Dunaev, is wounded and shell-shocked at the very beginning of the Great Patriotic War (World War II). Partorg Dunaev finds himself deep in a mysterious forest, where he inadvertently snacks on unknown hallucinogenic mushrooms. He subsequently transforms into an exceptionally strong wizard who is capable of fighting spectral enemies both on earth and in heaven. The reader discovers the so-called "parallel war" sweeping over the Russian territory where legendary Russian/Soviet fairy heroes are locked in combat with their opponents, the
\end{abstract}


characters of the Western children's tales, and books. A heroic mushroom-eater, Partorg Dunaev joins one of the sides in this fight and gradually reaches the "utmost limits of sacrifice and self-rejection." This article contextualizes the fungi-entheogenic episodes of Moscow conceptualism into a broader sphere of constructed visionary/ hallucinogenic reality by focusing on psilocybin fungi, particularly the fly agaric/ Amanita muscaria/Mukhomor, and their cultural significance.

\section{Keywords}

fly agaric - mushrooms - Amanita muscaria - Mukhomor - post-Soviet literature Russian Postmodernism - literature - Russian Conceptualism

1

\section{Introduction: the Amanita muscaria/Fly Agaric/Mukhomor Mushroom}

The importance of culture-specific dimensions in studying the use of psychoactive substances has been highlighted by a number of recent studies dedicated to the subject. ${ }^{1}$ Of particular interest are the issues of body politics and

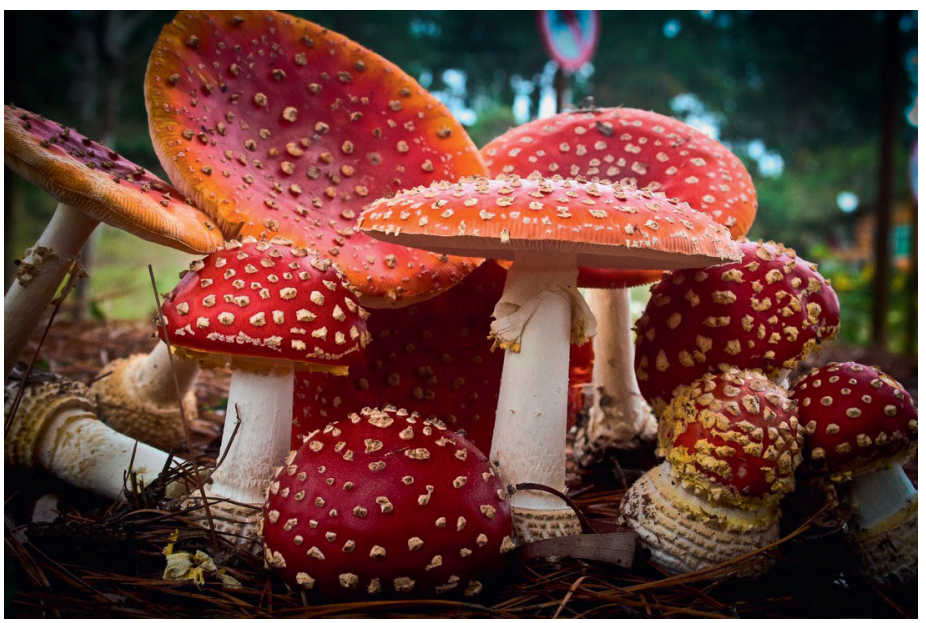

FIGURE 1 Amanita muscaria (fly agaric) [Russian: Мyхомор (Mukhomor)] REPRODUCED IN HTTPS://WIKIGRIB.RU/MUXOMORKRASNYJ/

1 Of particular relevance is Zinberg's tri-partite model of psychoactive agents which comprises the properties of drugs, the sets, and the settings, in which the set relates to the psychological effect on the user, and the setting refers to social context (Zinberg 1984; see also Millington, Maxwell 2014, 115-116). 
subversion of the norm in relation to psychoactive matter in Russian literature and culture, from the 19th century to the first post-Soviet decade. Anthropomorphic artistic representations of mushrooms and specifically, the Mukhomor (Amanita Muscaria, cf. Fig.1) constitutes one of the less explored topics in both Russian and world literature. The myconymic fashions of human existence make for a fairly intriguing segment of the world culture. Mushrooms employed as literary tropes standing for various signs of decay and rottenness are abundantly present in Shelley, Keats, Tennyson, Conan Doyle, D.H. Lawrence, and many others (like Emily Dickinson). ${ }^{2}$ The most notable case is of course H.G. Wells' fantastic story The Purple Pileus. The fungal traces are widespread in the modern period, we can think of authors such as Molière-starting from Tartuffe (etymologically a truffle) proceeding to the town of Molières which is found to the south of the River Dordogne, near to Beaumont du Perigord (a name that alludes to the suggested presence of the most valuable black truffles).

Many historically illicit drugs have been objectified as various products fit for human consumption, some have been legitimized by culture, some condemned, some are viewed as healthy, some as poisonous, many that were deemed a luxury were reconsidered as necessity, and they all form intersections filled with contradictions that encompass several of these categories. ${ }^{3}$

This study aims to contribute to the topic of representations of substances which have been ostracized and/or tabooed (in this case, hallucinationinducing mushrooms). They can be classified as stimulants, narcotics or intoxicants; ${ }^{4}$ many are articles of pleasure, healing, and sensual delight which, at the same time, are endorsed as necessities and staples. Their shifting status makes them a particularly suitable material for authorial subversion and challenges to the norm. A few recent and earlier Russian-language articles have been published that deal with ancient representations of mushrooms in the vast land of the 'Russian Eurasia.. 5

This article focuses on the subversive use of Eurasian themes and scenes involving ingestion (including the intoxicated urine of those who were drinking the fungal brew) and consumption of materials containing and producing

2 On this topic see among others: Arthur 2000; Hudler 1998.

3 For instance, such an innocent a material as chocolate was originally perceived as an aphrodisiac - a notion which persisted deep into the nineteenth century, but by the end of the century chocolate was already admitted as a nutritious morning drink for children (see Schivelbusch 1992, 92-95).

4 For the sake of the current discussion I use Schivelbusch's augmented categorization of these substances (Schivelbusch 1992, xiii).

5 See in particular such studies as: Belova 1996; Batyanova 2001;a; Batyanova, Bronshtein 2016; Dikson 2008; Vereshchaka 2014; Gordeeva 2017. 
138

IOFFE

psychoactive substances. At the center are the issues formed at textual intersections of substance-containing materials with the politics of state, class, gender, and sexuality expressing authorial subjectivities or alliances with the dominant discourse of the time. I share the opinion that in addition to being part of natore, material substances and the human body are also fluid cultural constructs. The paper offers narrative analysis of the ethnobotanical historiography and the hidden plots behind the younger group of Russian (Moscow) Conceptualists. It features a historiographic discussion of various ways of conceptualizing visionard mushroom-centered narratives that arise from Mifogennaia liubov' last [The Mythogenic Love of Casts] by Ravel Peppershtein and Sergei Anufriev. In what follows below, I examine mythopoeic and mythogenic themes in the comparative scholarship of mushroom-related beliefs (based on contributions by R.G. Wesson, V.N. Toporov, T.Ia. Elizarenkova, and many others).

The "mythopoetic" narratives and corresponding mushroom-eating proctices are discussed in order to attain a better contextual understanding of the novel. As I will try to demonstrate, in some parts of the Russian empire there existed beliefs based on a strong mythological and religious syncretism between mushrooms and men. Such was the notion of the so-called Liudi Mukhomory (Fly Agaric Men, cf. Fig. 2; Fig. 3) which has recently been extensively studied by Batyanova and Bronshtein (2016, 46-59) who have also published the extremely rare ancient Siberian petroglyph s depicting the unique breed of fungi and humans:

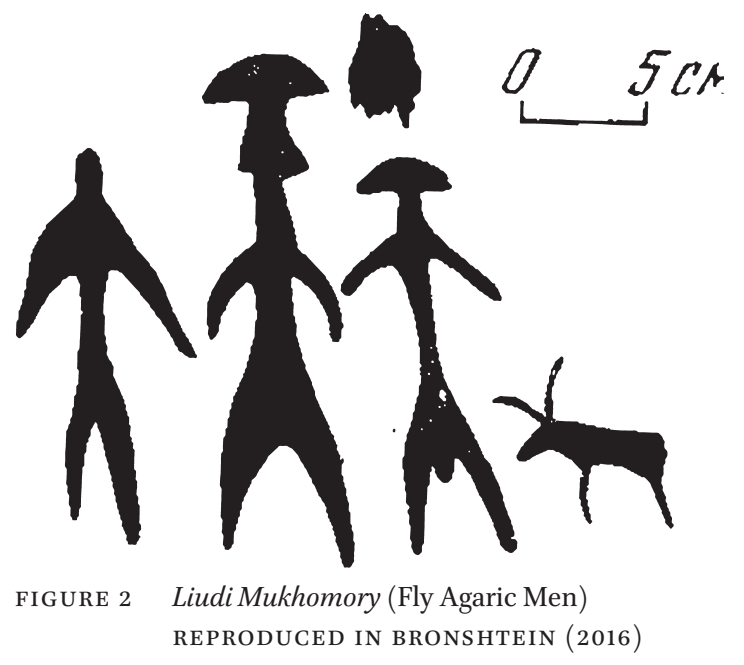

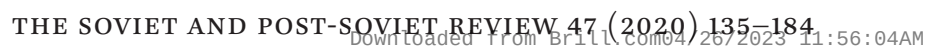

via free access 


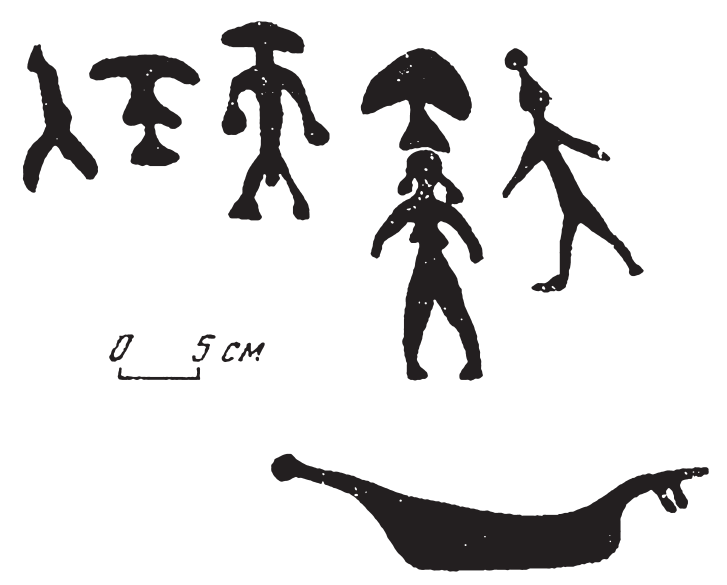

FIGURE 3 Liudi Mukhomory (Fly Agaric Men) REPRODUCED IN BRONSHTEIN (2016)

One of the goals pursued by this study is to explore connections between this intriguing imagery and certain traits in the recent Russian conceptualist fiction. Therefore it is preoccupied with reflecting on ethno-botanical entheogens (the term signifies a certain substance, plant or drug consumed in order to elicit a spiritual experience, i.e. "generate the divine within") which appear to be related to the psilocybin fungi used by the communist Vladimir Dunaev, the protagonist of Peppershtein and Anufriev's text. This article connects the fungal topic of the Post-Soviet novel with preceding depictions of a mushroom/godly human in literature and culture, e.g. the God Soma as Mukhomor (Wasson), Jesus Christ as Mukhomor (John Allegro), and Vladimir Lenin as Mukhomor (Solzhenitsyn, Kuriokhin).

This article not only looks at the symbolic semiosis of mythopoetic (literary and cultural) dimensions of the fungal theme, but offers an overview of some significant 'material' qualities of mushrooms. This subject fits by a wide margin into the dialectic framework of transhumanism. The aim is to trace the transgressive historical trend of blurring boundaries between a fungus and a human and vice versa. This unique vision goes back to the pre-historical rock-paintings (petroglyphs) recently found in Chukotka, displaying imagery of the fusion of human/fungal bodies. (See below. See also Kruichkov 2008; Georgievsky 2016).

In their two-volume epic novel Mifogennaia liubov'kast [The Mythogenic Love of the Casts] (1999), Pavel Peppershtein and Sergei Anufriev offer a sequence 
of meticulously described hallucinogen-induced scenes reminiscent of other renowned instances of psychedelic prose. Non-Russian texts of this kind were composed in their time by Thomas De Quincey, Ken Kesey, Antonin Artaud, William Burroughs, Jack Kerouac, Paul Bowles, and "the most dangerous man in America" (as per Richard Nixon), Timothy Leary (see Leary 1998). ${ }^{6}$ There have also been respective movie adaptations by Alejandro Jodorowsky and Raoul Ruiz. For argument's sake I will leave aside the varieties of the narcotic tradition represented in Russian literature by such texts as Mikhail Bulgakov's Morfii [Morphine] (1927) and Mikhail Ageev's Roman s kokainom [A Love Affair with Cocaine] (1934) that are not directly and explicitly related to the fungal theme. Likewise, I will have to omit discussions of narcotics in the Russian literary universe in general. ${ }^{7}$ Instead, I will limit my debate to hallucinogenic fungi and the complex relationship between mushrooms and humans. ${ }^{8}$

At the very beginning of the Great War, a Russian party functionary (Partorg) named Vladimir Petrovich Dunaev is heavily concussed, subsequently finding himself deep in the Russian magical woods where he is somehow impelled to taste hallucinogenic mushrooms facilitating his conversion into an omniscient militant wizard. ${ }^{9}$ The attentive reader will uncover the so-called "parallel war" unravelling on the Russian territory: fairy-epic heroes and characters from children's books are fighting on both sides of the conflict. The authors of this experimental text are two Russian conceptualist artists who have also pursued careers in writing. Moscow Conceptualism has habitually rejected the traditional separation of image and word. Mifogennaia liubov' kast was initiated in order to "apply" Andrei Monastyrskii's theory of art to a prosaic text piece. ${ }^{10}$ It was a long-conceived project that someone in that circle had to carry out, and both authors did so, first and foremost, as (Moscow Conceptualist) artists rather than authors embarking on their own and unrelated literary adventure.

Pavel Peppershtein (b. 1966), one of the founding members of the artistic group "Inspektsiia MedGermenevtika" (Medical Hermeneutics Inspection) is widely known as one of the headmost Russian conceptualists of the younger generation. Curiously, he can be viewed as closely related to two prominent

6 The other corresponding author here must be McKenna 1999.

7 Such as Anna Karenina's use of narcotics, or the function/role/image of various narcotics in Valerii Briusov's Diary.

8 On the related field see Munn 1973, 86-122, as well as Arthur 200o. See also Ruck, Heinrich, Staples 2001.

9 Cf. such reviews as Ryklin 2000 or Danilkin, Brashinskii 2003.

10 See Ioffe $2013 \mathrm{~b}$. 
Russian Conceptual master-artists-his father Viktor Pivovarov, and Ilya Kabakov. ${ }^{11}$

Inspektsiia MedGermenevtika was founded in 1987 and included, along with Peppershtein and Anufriev, Iurii Leiderman and Vladimir Fedorov. Since its very inception, it has been part of the larger Moscow artistic circle called Noma (1988). The latter is the informal union of Moscow conceptualists known best for defining (and defying) their intellectual boundaries with the means of a peculiar sort of collective discourse. The formal concluding year of the group's existence coincides with the 9/11 Act of Terror in New York. Some 10 exhibitions were held between 1989 and 1997, usually outside Russia: in Prague, Munich, Milan, Vienna, Cologne, and other European cities.

The initial genesis of the group was fomented by Dmitrii Prigov who is rumored to have persuaded its founding members (especially Peppershtein) to actively work together. Andrei Monastyrskii has also exercised his powerful personal influence over the group (Groys 2003, 240-245). Their final "postmortem" collective exhibition was held in Moscow as late as in 2012 to commemorate the extraordinary length of the group's collective memory. Moscow conceptualism usually maintains a very special relationship with all things verbal and literary (Ioffe 2013b, 210-230). ${ }^{12}$ The Medical Hermeneutics group is no exception, and nearly all of its participants occasionally tend to circulate texts of their own making. The group even used to have its own quasi-Samizdat journal titled Mesto Pechati [A Venue for Publication or Place of the Seal] disseminated by the Moscow underground gallery Obscuri Viri. ${ }^{13}$

As is usually the case with Moscow Conceptualism, the group's creed appears to be rather suggestive. The conceptualist "collective mentality" (reinforced by collective actionality) constantly referees ideological borderlands, trying to deform the "normal" state of consciousness. The group does not view this kind of state in a positive light but rather acknowledges it as a sort of disease, which should be treated and cured. During the process of "therapy"

11 As Peppershtein recollects his growing up "near Kabakov" — “... at some point Ilya told me: you're stuck inside some kind of egg. It's time to hatch out and start realizing your full potential?” ("В какой-то момент Илья стал говорить мне: что ты сидишь в каком-то яйце, ты не хочешь уже вылупиться? Никаких потребностей в самоутверждении или самопроявлении я не испытывал, но Илья довольно нетерпеливо начал пинать меня и говорить: давай вылупляйся уже, давай реализуй себя по полной"). Vekhova 2019 .

12 See also Esanu 2012.

13 On this milieu, see a detailed first-hand account by Wenzl 2012. 
several things can transpire, not necessarily related to the situation but tending to transcend its boundaries. The very term "Medical Hermeneutics" reveals a huge amount of hidden irony characteristic of Russian Conceptualism in general. ${ }^{14}$ One of the crucial problems that the group was focusing on was the issue of self-identification and self-reflection. As one of its leading members (Peppershtein) would observe, they tried various titles such as "inspectors, the incorrupt officials of the era of faded flags," "dogmatic inspectors of schizophrenic China," "experts in the formation of aesthetic categories," "masters of sense-construction," and so forth. ${ }^{15}$ Peppershtein mentions the fact that he usually enjoys pathos, especially when it comes to unearthing certain comical aspects buried within it. He often writes and paints in the peculiar state of "hallucinogenic" affectivity which is suggestively related to the way we accommodate and perceive any given trance experience. This is what he terms a "hallucinogenic compromise" between defamiliarization/estrangement and the artistic participation. ${ }^{16}$

Peppershtein is often considered ${ }^{17}$ a founder and a main ideologue of the movement of "psychedelic realism" which relates to certain artistic currents in the 1990s that employed traditional ("classical" or "mimetic") forms of realistic art in order to fill it with vivid hallucination-like imagery that was not always easily accessible to the non-engaged viewer. As Boris Groys observed, "Peppershtein invests his energy in creating microsocial groups brought together by common ideology."18 To Groys, "Inspection Medical Hermeneutics" is reminiscent of the story of "a European ethnologist who wanted to disabuse an African shaman of the alleged superstition that all events in the world proceed from good and evil spirits."19 Peppershtein's colleagues offer their inspecting

14 On the various way to juxtapose Russian Conceptualism (e.g. for instance Eysk) vs the Moscow one see J. Janecek 2006, 469-487; Also see Ioffe 2014, 339-359; Ioffe, Oushakine 2013.

15 Seе: «Инспекторы-неподкупные чиновники эпохи выцветающих флажков", "инспекторы-начетчики шизофренического Китая», «специалисты в области становления эстетических категорий”, “специалисты по обустройству смыслов». (Peppershtein 2005, 380; Monastyrsky 1999, 174).

16 Cf. "Мне очень нравится пафос, я в нем нахожу таинственные комические аспекты. Я часто пишу в состоянии галлюциноза, и многие в каких-то трансовых состояниях могут почувствовать или увидеть то же самое. [...] С психологической точки зрения представляет собой скрыто галлюциногенный компромисс между 'отстранением' и “участием”.' See Peppershtein, “Obo mne”, Snob, http://snob.ru/profile/5323.

17 See Groys, Inspektsia....

18 Groys, 2003, 243.

19 Groys 2004, 199. 
services for playful interpretation of cultural and textual phenomena. As Groys points out,

[T] he texts and images of the group always refer to many other texts and images, from Thomas Mann and Arthur Conan Doyle, to Soviet children's book illustrations from the sixties and seventies. These texts and images repeatedly reveal empty spaces, seemingly chance constellations of words and images that are abound with meaning. Pavel Peppershtein and his co-authors have no fear of any risk of 'over-interpretations'. On the contrary, the group's method is the method of rigorous over-interpretation. For Peppershtein is well aware that even the boldest over-interpretation cannot escape the fate of all interpretations: namely that they ultimately remain under-interpretations. ${ }^{20}$

In order to assist the reader in addressing these perplexing matters, the authors of the novel embed all kinds of mythical, folkloristic, and other characters in the text's fabric where we encounter Baba Iaga, Koshchei the Deathless, Karlsson-on-the-Roof, the magic Geese-Swans, and other figures of that mythogenic kin.

The novel plays with various fairy-tales and myths (Russian and Slavic as well as non-Russian and non-Slavic). It presents an alternative, mythogenic version of the Second World War. The real struggle appears to be not between human troops and armored tanks: it is a war between ghosts and heroes of European fairy tales and children's books and their Russian/Soviet/Slavic counterparts. The true hero of the novel, Vladimir Dunaev, becomes a magic medium in this covertly conducted suggestive warfare. Dunaev, the mushroom-eater, sides with the forces of the so-to-say "Good" in this campaign. ${ }^{21}$

It might be worthwhile to examine this method of constructing visionary hallucinogenic episodes in the broad context of multi-cultural and intertraditional practices involving the psilocybin fungi. In what follows, I will review some of these traditions, both Eurasian and Amerindian, which might help to decode the particularly broad spectrum of possible meanings offered

20 Groys 2004, 200. (emphasis added-DI).

21 Notwithstanding that, Mifogennaia liubov' kast does not really seem to be about "good" and "evil". The Germans are aggressors, and to that end they bring their mythogenic archetypes with them, whereas the Russian archetypes are merely working on the defensive, as is their fundamental duty. There is more or less nothing inherently good or bad about those archetypes on either side. 
by the "Medical Hermeneutics." The theoretical frame of this article is founded on the ideas of the cultural-material turn and new materiality ${ }^{22}$ as it becomes visible throughout the novel's grand-text. The complex relations between the fungus and the human body, between the materiality of phantasm and the semiotics of the literary text will remain at the focus of this article. ${ }^{23}$ It is symbolically divided into two parts: 1 ) the iconographical suggestive background depictions found in historical documents which, as I argue, served as a source of major inspiration for the authors and possibly lie at the foundation of the Peppershtein-Anufriev oeuvre, and 2) specific literary episodic examples translated into English for the first time. ${ }^{24}$

\section{2 \\ The Hallucinogenic Traditions of the World}

Below I will deal briefly with some major variations on the theme of mushrooms and hallucinogenic fungi that were most likely known to both authors of the analyzed text. ${ }^{25}$ From many indirect sources we learn that Peppershtein and Anufriev had a first-hand experience with various kinds of "substances" that result in a state of hallucinogenic consciousness. We can solidly postulate that the authors were profoundly familiar with both the Russian indigenous mushroom-eating tradition (the mighty Mukhomory of Siberia), and the Mesoamerican layer. ${ }^{26}$ This non-Russian material came evidently from the "Beatnik" (1950s) and Woodstock-scented (196os) rebel cultures which became gradually known in the USSR especially during Perestroika (the formative period for Peppershtein's group). Closely related to this connection would have been a probable influence of Carlos Castaneda whose famous yagerelated books gained formidable popularity on Russian post-Soviet territory. Castaneda has been widely translated into Russian and published in dozens of

22 Cf. the state of the art of this topic in Smith, Meyers, Cook 2014 and Hicks, Beaudry 2009. From the Slavic point of view, see Kujawska 2014.

23 Some of these matters are naturally included within the broader theme of shamanism and its substances (Harner 1973).

24 All translations in the text are mine unless indicated otherwise.

25 Aside of Castaneda, some of the informative standpoints relevant to both Peppershtein and Anufriev might be found (chronologically speaking) in such publications as La Barre 1990, 261-278; Levi-Strauss 1970, 5-16; Du Toit 1977; Clark 1969.

26 On other related traditions (e.g. Ayahuasca and other substances of the region), see in particular Ott, Bigwood 1978; Radin 1970, 84-91; Reichel-Dolmatoff 1972, 84-113; Schultes, Hofmann, Ratsch 2001; Valdes, Hatfield, Koreeda, Paul 1987, 283-291; Shanon 2003; Weiss 1973, 39-48; Wilcox 2003. 
thousands of copies. His psychedelic oeuvre, whose overtones betray distinct postmodernist spiritus, could have been considered a natural object of interest by the younger Russian conceptualists who were engaging themselves in the peculiar topic of hallucinogens. ${ }^{27}$

Carlos Castaneda's transgressive influence on the fungal theme in Russian poetry can be illustrated by a poem called "Mushroom Picking Trip" (Поездка по грибы) (1993-94), authored by Viktor Krivulin, a prominent poet of the Leningrad samizdat milieu:

... a fungal Mexican soul/ possesses, with no demand of care, the mycelium of a roadside folk/ and grows there, moist and trembling/ new spores are ripe./ a hunt for toadstools: the naked surface of teary mold is so fresh under knife's edge this morning!/ the weather's nippy.// truck beds scatter mushroom pickers across Castaneda's enchanted forest/ and rot in ditches at the end of summer/ but they will all return/ no kidding whatsoever/ they will come back with their mucous booty and an aftertaste of victory.

... грибная мексиканская душа

вселяется не требуя ухода

в грибницы придорожного народа

и там растет сырея и дрожа

созрели споры новые. охота

за мухоморами: как поутру свежа

слезливой плесени под лезвием ножа

поверхность обнаженная! погода

ядреная. рассыпав грибников

по заколдованному лесу кастанеды

в кюветах кузова грузовиков

гниют пустыми на исходе лета

но все вернутся-все, без дураков,

с добычей слизистой и привкусом победы ${ }^{28}$

27 Along with Burroughs and Ginsberg, Castaneda deserves a place of honour among the potential influencers on this branch of Russian Conceptualism. For the context see Burroughs, Ginsberg 1963. On such non-fungal experiences including Ayahuasca see in particular: de Rios 1984; Luna, Amaringo 1993; Naranjo 1995, 391-399. Opler 1970, 31-47; Osmond 1970, 67-86; Ott 1994; Allen 1997; Anderson 1980; Boyer, Basehart 1973, 53-67. 
Long before Castaneda, Herodotus described the well-developed narcotic habits of the inhabitants of Scythia (a historic region that at least partially lay within the borders of the Russian Empire). In Herodotus' History (IV, 4) we read, in particular:

... the Scythians take some of this hemp-seed, and, creeping under the felt coverings, throw it upon the red-hot stones; immediately it smokes, and gives out such a vapor as no Grecian vapor-bath can exceed; the Scythians, delighted, shout for joy, and this vapor serves them instead of a water-bath; for they never by any chance wash their bodies with water. ${ }^{29}$

It is well acknowledged that the religious use of hallucinogenic mushrooms has been practiced among many cultures of the globe: from Mexican Indians to Siberian natives.

It must be stressed that any scholarly debate on the topic of psilocybin fungi should start with R. Gordon Wasson, the pioneer mushroom-connoisseur who authored the famous and highly influential hypothesis about the widest diffusion of the Amanita muscaria (Mukhomor') in the archaic cultures of Eurasia, namely in the cultural strata of the Vedas. Wasson's main "test-case" was the mysterious and suggestive Mukhomor-based image of Soma (the god and the divine food of high importance in the hymn-poetry of Rigveda). ${ }^{30}$ The same topic was masterfully researched in the scholarship of the eminent Russian Sanskritologists and cultural historians Vladimir N. Toporov and T. Ja. Elizarenkova. ${ }^{31}$

The foundation of this scholarly (myco-centered) agenda was further promoted and developed in a series of scholarly works by the "mycological couple" of Wassons. Not only Gordon Wasson himself (who did not know Russian) but also his wife Valentina Pavlovna, who translated many of the important Russian "mushroom-centered" texts for him, should be honored on this occasion (Wasson 1957, 1971). ${ }^{32}$ The joint two-volume monograph by the Wassons (published in 1957, one year prior to Valentina Pavlovna's unexpected death) deals with the many facets of folk and literary history, linguistics, and art pertaining to the hallucinogen fungi of the world with special attention to Russia. The mycological Wasson couple devoted several decades to a meticulous study

\footnotetext{
29 See the context in Riddle 1992.

30 Wasson 1971. See also Dunn 1973, 488-492, Brough 1971, 331-364

31 See Elizarenkova, Toporov 1970, 40-46; Toporov 1999, 232-299.

32 Cf. Wasson 1957; Wasson 1971.
} 
and systematic accounting of the wild-growing psilocybin species of all sorts. This endeavor finally resulted in the two-volume masterpiece preoccupied with descriptions of mushroom-related practices in various cultural traditions of the world (Wasson 1957). ${ }^{33}$ The Wassons were utterly convinced that religious veneration of mushrooms was very popular and widespread among the Eurasian population as well as the American. The psychoactive entheogen fungi as described by the Wassons exercised enormous influence on the general state of creative minds in the contemporary Western culture (Hudler 1998; Riedlinger 1990). ${ }^{34}$ Narcotic plants and their peculiar religious and cultural use constitute an extremely important chapter of Asian and Eurasian history (Abdullaev 2009).

Nearly all the generations of the "psychedelic youth" have been genuinely fond of the Wassons' writings, and we are bound to conclude that all the prominent "hallucinogen-seekers" like Timothy Leary and especially Carlos Castaneda were profoundly indebted to their contribution to the field. As one notable scholar put it with reference to the Wassons' life story:

... In the fall of 1952, Gordon and Valentina Wasson learned that the sixteenth-century writers describing the Indian cultures of Mexico had recorded that certain mushrooms played a divinatory role in the religion of the natives. ${ }^{35}$

After R. Gordon Wasson, the subsequent scholarship sometimes commonly perceived the Vedic figure of "Soma" (both the brew and the deity) as a conceptual associate to the famous Mesoamerican drug-plants and Entheogenic practices. ${ }^{36}$ In their turn, Peppershtein and Anufriev, theoretically speaking, might have purposefully secured their grasp of Soma through the Avant-Garde postpunk psychedelic band of American exiles in Europe called "Tuxedomoon" whose accordingly named 1985 composition features these lines:

33 See also Sandford 1973 and the Wasson's additional studies on related topics ranging from Mesoamerica to Europe (Wasson 1974; Wasson, Ruck, Hofmann 1978; Wasson 1979; Wasson 1980; Wasson 1986).

34 Their influence is also felt in the non-fungal world of hallucinogens (de Rios 1976; de Rios 1977, 265-268; de Rios 1984).

35 Furst, Peter T. 1992a.

36 Among a great number of studies, see Harner 1973; Heinrich 2002. For additional comparative material one might use the collection Ott, Ruck 1986, 140-149. 
Now there's Soma the miracle drug

Soma the miracle drug, have you tried Soma?

The miracle drug, it's the turn of the century

No more lows, no doze, no nerves

Just an endless ride

No more sick, no more hell, no more confusion

Now there's Soma. ${ }^{37}$

Aside from Gordon Wasson, we should mention another important scholar who pioneered the study of psychoactive entheogens. This is Richard Evans Schultes, the former Director of the Botanical Museum at Harvard University. In his notes he describes some important details of mycological ethnobotanical subjects:

... The use of hallucinogenic substances goes far back into human prehistory. There have been suggestions that even the idea of the deity might have arisen as a result of their weird and unearthly effects on the human body and mind. ${ }^{38}$

This view on the "mushroom nature" of the Highest God is harmoniously reconcilable with the somewhat scandalous approach of the American Qumran archaeologist John Allegro to the identity of Christ-as-a-Mushroom (Allegro 1970). This scholar tried to substantiate his theory that early cults of historic Christianity (during the period of the Second Temple) extensively used the fly agaric for various religious purposes. Allegro's main thesis maintained that the Amanita muscaria itself was deified as a cultic object by the Israeli Essenes community and was actually worshipped as a substitute for Jesus Christ Himself. He further suggested that a big mushroom (Mukhomor) might have been physically crucified to impersonate the figure of the divine founder of Christianity. This approach was widely critiqued in academia and beyond (King 1970). The very approach of John Allegro to the topic of mushrooms

37 See "Soma", Tuxedomoon: Holy Wars, CD. 1985. On the circulation of Western Rock in Russia see in particular: Friedman and Weiner 1999, 110-138. See also Spess 2000. By the end of the 1980s (the end of Perestroika and the time of Medical Hermeneutics' formation) Western Rock and experimental music was already quite well diffused among the connoisseurs and circulated more or less freely without any repression from the declining Soviet authorities, especially in Moscow and Leningrad. On this in particular see Chernin 2006. 
and Christianity is very much in line with Mifogennaia liubov' kast in terms of their far-reaching hallucinogenic view of reality, and especially because of their conceptual blurring of boundaries between human flesh and that of a fungus. Accepting anthropomorphic dimensions of fungi also results directly from Allegro's bold (and blasphemous) hypothesis.

According to Wasson, the use of hallucinogenic mushrooms is even more ancient than was deemed by Allegro, representing an integral core element of many mutually distant and unrelated human cultures of our planet. It has been postulated by a number of scholars (with plausible arguments) that the very concept of a deity may have arisen from the effects of mushroom consumption and that their present disjunctive ritualistic use in primitive religious-magic systems is relict (Stamets 1978). Wasson observes that since the earliest times, mushrooms

... have been worshipped by certain primitive peoples scattered from Mexico to Borneo and Siberia, and we think formerly in Europe, too. The visions [...] are staggering in their subjective impact. [...] If we are right in one conjecture that the secret of these mushrooms was discovered by early man, perhaps very early as he was emerging from his bestial past [...] Our hallucinogenic mushrooms opened to him conceptions and emotions theretofore beyond his reach ... yes, perhaps the very idea of a Superior Being. ${ }^{39}$

\section{The Historiography of the Russian and Eurasian Traditions of Mushroom Eating (Siberian Psilocybins)}

There is little doubt that the authors of Mifogennaia liubov'kast were mindfully resting their Dunaev narrative on the available accounts of Mukhomor-eating world practices, and in the first place, naturally and most particularly those related to the Siberian ("Russian") authentic indigenous usage of these mushrooms. In agreement with Wasson, Schultes also emphasized the specific importance of the Siberian hallucinogenic mushroom (Mukhomor) as fundamental for nearly the entire historical debate on the religious use of psilocybin. Amanita muscaria is probably "the oldest and once most widespread in use of the hallucinogenic mushrooms." As the scholar observes, "it grows throughout the north-temperate parts of both hemispheres" (Schultes 1969). The famous 
Swabian medieval theologian scholar Albertus Magnus of Cologne (1200-1280) is usually mentioned as the first one who actually dealt with Amanita muscaria in Western "science." In his tractate De Vegetabilibus [Liber de Vegetabilibus et Plantis] (c. 1256) he writes: "vocatur fungus muscarum, eo quod in lacte pulverizatus interficit muscas" (Wasson 1961, 137-162)..$^{40}$ We should also be mindful of the specific epithet ${ }^{41}$ given to it by none else but Carl Linnaeus (1707-1778). This Swedish scholar (also known by the name of Carl von Linné) was a prominent researcher of botany and zoology, particularly famous for introducing the modern biological naming system of "binomial nomenclature." The father of the Latin name of Mukhomor, Amanita muscaria, is also known to be the one creating scientific taxonomy and even modern ecology. The name that Linnaeus gave to this mushroom echoes Albertus Magnus and obviously alludes to an older habit of, as Schultes puts it, "employing the caps of the mushroom to repel and kill flies". Linnaeus deals with Mukhomor in the second volume (Tomus II) of his Species Plantarum (1753) where he chose Agaricus muscarius $^{42}$ to denote this mushroom from then onwards. Thirty years later, in 1783 , the respective genus Amanita was officially registered in botanical science by Jean-Baptiste Lamarck, whereas Amanita muscaria became scientifically recognized as a species in 1821 by Elias Magnus Fries, who is often referred to as the founding father of modern mycology (see Ramsbottom 1954). According to Schultes, the use of the fly agaric as an inebriant was broadly known in Eurasia since the ancient times. He mentions the evidence of the Mukhomor usage

... in extreme western Siberia, amongst Finno-Ugrian peoples, the Ostyaks and Voguls; and extreme north-eastern Siberia, amongst the Chukchis, Koryaks and Kamchadals. [...] The Yukaghir, peoples surviving in tiny communities and speaking an isolated language in North-Eastern Siberia, remember that their forbears made use of the mushroom. There seems to be every probability that the fly agaric might once have been employed all the way across Siberia and into Europe ... ${ }^{43}$

40 "It is called the fly mushroom because it is powdered in milk to kill flies" (Book II, Chapter 6; and Book VI, Chapter 7). See on this further Ramsbottom 1954.

41 I.e. the term Amanita muscaria (Mukhomor) which identifies the initial idea of "exterminating the flies," esp. based on its name in Russian. See Shapovalov 2001; Waser 1968, 19-20; Vereschaka 2014; Wasson 1967, 405-414; Kir'jak 1998, 105-123; Furst 1992-a.

42 Musca is the Latin term for "fly."

43 Schultes 1969. 
The arguments that seem to support this research strategy are well grounded and can be found mainly in the studies of cultural anthropology and comparative linguistics on the various relationships and meanings in the field of mycology and ethnobotany. It has also been argued with confidence that the ancient berserkers of Norway induced their occasional fits of madness by ingesting Amanita muscaria (Fabing 1956, 232-237). ${ }^{44}$ As Schultes (1969) is keen to argue, only since the middle of the 18 th century "have reports concerning the utilization of fly agaric amongst Siberian tribesmen come to the attention of Europeans." The scholar mentions that those earliest reports were characterized by "appreciable diversity of opinion concerning the use of the mushroom, although all agree on its ritualistic importance and, in general, on its biological effects" (Schultes 1969).

The reports in question were originally provided by a Swedish officer and geographer Philip Johan von Strahlenberg (1676-1747) who participated in the Northern War and then fell into Tsar Petr's captivity during the famous Battle of Poltava (1709). Until 1721, he was imprisoned in the town of Tobol'sk, using his time and location to conduct some meaningful research on Siberian folklore, religion, and geography. He also had an interest in shamanic rituals performed by the autochthonous tribes who, as he did not fail to mention later, openly consumed the Mukhomor. The French translation of Strahlenberg's text Description Historique de l'Empire Russien appeared post mortem (1757) in Amsterdam (being edited and prepared in Paris), published by "Chez Desaint \& Saillant."

The renowned Russian academician-explorer Stephan Krasheninnikov (1711-1755) was probably the first scholar ever to complete a detailed report about the Kamchatka region in the first half of the 18th century wherein he also gave a valuable depiction of various customs of the local tribes: not only of the Kamchadals but also of the Koryaks. As Richard Schultes observes, Krashenninikov was the first known Russian to take notice of the Mukhomor rite of the Koryaks. Krashenninikov wrote in particular that:

[s]ometimes for the sake of merriment they consume the Mukhomor, a well-known mushroom that we use to repel flies. They marinate it in epilobium wort and then drink it or, more often, just roll the dried mushrooms up and swallow them whole. [...] For moderate consumption they 
take four mushrooms or less, while for getting really drunk the number would be up to ten. ${ }^{45}$

Since the time of Krasheninninkov, many anthropologists and various writers have taken interest in the fly agaric rituals and performance practices in Siberia. Schultes justly points out that Siberian worshippers/smokers/eaters of Mukhomor had no other intoxicant before the Russians introduced alcohol. The intake of Amanita muscaria, according to Schultes, was to all appearances more common among the Koryaks than the Chukchis and Kamchadals,

... probably because, since they inhabited the most heavily forested areas of Kamchatka, the mushroom grew more abundantly in their area. It is thought, furthermore, that the Koryaks supplied much of the mushrooms consumed by their neighbours. Amanita muscaria was usually not taken fresh, but dried, either in the sun or over a lit fire. ${ }^{46}$

Schultes adds that another German-Russian explorer, Georg Heinrich von Langsdorff (Baron de Langsdorff, 1774-1852), cared to remark that Mukhomors

... are collected in the hottest seasons and hung up by a string in the air to dry; some dry of themselves on the ground and are said to be far more narcotic than those artificially preserved. Small deep coloured specimens, thickly covered with warts, are also said to be more powerful than those of a larger size and paler colour. ${ }^{47}$

The Slavic ethnobotanical tradition is full of purposeful handling of mushrooms in various exempla of magic lore (Svanberg, Łuczaj 2014). This topic has been studied copiously: a good example is Valeria Kolosova's series of valuable works on the subject. Kolosova notes the peculiar resemblance between various anthropomorphic perceptive forms popular with the Slavs, on one hand, and certain forest fungi, on the other. This resemblance is rooted in the very process of Slavic name-giving, which is supported by abundant evidence in

45 Krashenninikov 1994, 108, 110. «Иногда употребляют для веселья и мухомор известной оной гриб, которым у нас обыкновенно мух морят. Мочат его в кипрейном сусле, и пьют оное сусло, или и сухие грибы свернув трубкою целиком глотают, которой способ в большем употреблении ... Умеренное употребление-это четыре гриба или меньше, а для пьянства едят до десяти грибов.»

46 Schultes 1969.

47 Schultes 1969 . 
Russian folklore. Kolosova mentions one particularly fascinating folklore tradition related to a woman's ear which is perceived as a mushroom sui generis. In Peppershtein's and Anufriev's novel, Dunaev's mythogenic mushrooms are often implicitly androgynous, and his consumption of them, devouring of their flesh might resemble the ritualistic ceremony of Eros and Thanatos who were going hand in hand together, whereas their mutual sensual "eating" was a remote equivalent of consuming semen and having sex. ${ }^{48}$ According to Kolosova, mushroom's pliable, porous flesh resembles that of a feminine ear:

babie ucho, babieusz, babyjusy 'строчок обыкновенный' Gyromitra esculenta, реже другие виды грибов, или рус. диал. bab'e uұo 'деформированный, патологически изменённый гриб' (чаще в северно-российских говорах), болг. бабино уо, бабино ушинцъ 'древесный гриб, похожий на ухо'49

This babie ukho (woman's ear) in Slavic lore is nothing else but a "deformed, pathologically mutated mushroom." One might suggest that a woman's ear can serve as a natural metaphor for an accommodating vagina, soft and flexible. Georges Bataille would liken a vagina to an eye, ${ }^{50}$ so there is no reason why it could not be compared, so to speak, with an accommodating, gentle ear.

48 In Russian folk-etymology the two verbs ecms ('to eat') and emu ('to penetrate someone sexually') appear to be obviously Paranomasi(a)cally interrelated as were their past participle forms поел ('he ate') vs поял ('he copulated'). Another common etymology relates the word истина ('veritable truth') to есть ('to eat'; plus, in a certain form, 'to exist') and emb ('copulate'), suggesting that in Slavic lore one is supposed to consume the truth in an erotic fashion. This looks also like a Biblical semantical borrowing, since in the Hebrew Bible ladaat isha ('to know/penetrate a woman') means to have an active sexual intercourse with this woman. Calqued into Church Slavonic and Russian as poznati ('to know/penetrate a woman'), a clear Bibleism. Another quasi-etymological correspondence between the Biblical Hebrew and Slavic lore is the term ielda ('phallus') having a pseudo-Hebrew provenance is related to ialad or ialda ('gave birth') and ultimately ieled or ialda ('the feminine/masculine offspring'). Persian yalda is also mentioned in this respect. Gnostic gems depicting the Demiurge Yaldabaoth (Ialdabaoth) appear to be profusely obscene, bearing grossly erected monstro-phallic imagery. "Eating" the truth also has many hard-core erotic implications in modern English colloquial usage. A recent example is the famous press-conference of the late Toronto Mayor Rob Ford where he declared that he has "more than enough to eat at home" while pointing at his confused spouse who happened to stand beside him: National Post, Toronto, November 14, 2013; url accessed April 27, 2015. http://goo.gl/qM3rzc.

49 Kolosova 2008; 2009; cf. also Ippolitova 2008.

$5^{\circ} \quad$ As per his L'histoire de l'oeil (1928). 


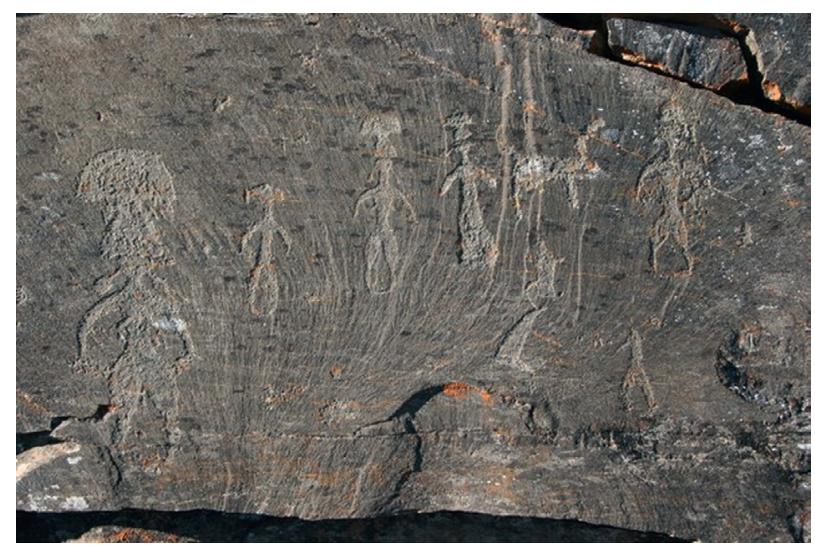

FIGURE 4 Chelovek-Mukhomor (Human-Amanita muscaria) at Chukotka archaeological site

PHOTO REPRODUCED IN KRIUCHKOV 2008

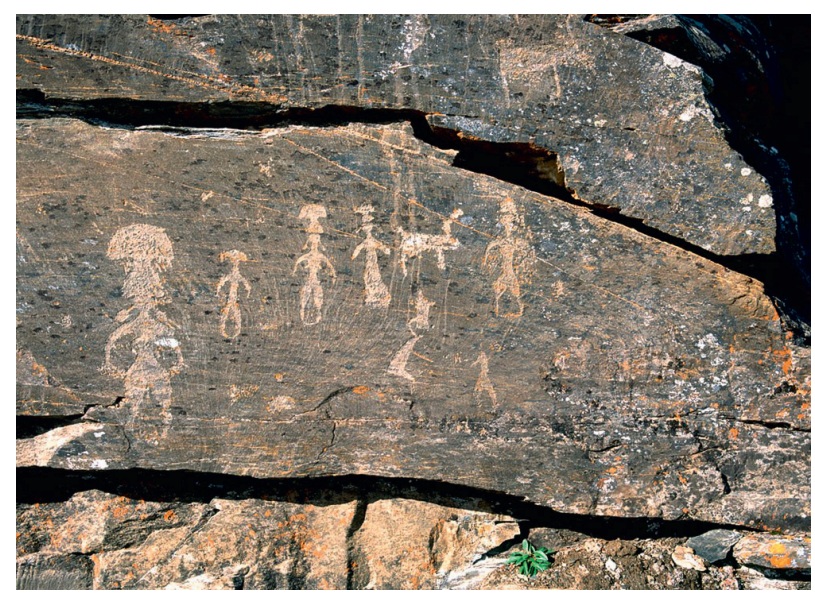

FIGURE 5 Another photograph of the same petroglyph site in Chukotka, which displays the examples of human-mushroom syncretism REPRODUCED IN GEORGIEVSKY 2016

Below, I will recount several intriguing details of the Chukchi/Koryak mushroomeating practices along with their peculiar human-fungus relationship, (cf. Fig. 4; Fig. 5) that were recorded by the well-known Russian ethnologist W.G. Bogoraz. ${ }^{51}$

$5^{1} \quad$ See his several well-known scholarly volumes published on this topic. 


\section{Consuming the Mushroom}

As mentioned before, Richard Schultes was one of the pioneers in the field of scholarly analysis of the perplexing topic of the fly agaric. He provided us, moreover, with a plenitude of descriptions showing how the process of mushroom consumption was actually conducted among the indigenous natives:

... Apparently only men ate fly agaric amongst all of these tribesmen, excepting in rare cases when a woman held the position of shaman. The method of using the mushroom varied significantly amongst the sundry tribes. The Koryak women moistened and softened the agarics in their mouth, then gently rolled them by their hands into small sausage phallic shapes and gave them to the men to swallow. ${ }^{52}$

This ceremony seems to have had a certain erratically erotic subtext, probably one related to gender-swapping.

Schultes deals with additional methods of consuming the Mukhomor which involved adding it to various dishes such as soups, sauces, cold or warm reindeer milk, or steeping it in fruit juice. In the more recent times, the mushroom was even drenched in alcohol in order to enhance the resulting intoxicating power. The scholar points out that there is much diversity of opinion concerning the length of the intoxication, i.e. it is believed that the effects of three or four dried or smoked mushrooms might range from four hours to a full day. The practice of consuming the Mukhomor informs a great deal about the social habits of the indigenous people. As Schultes observes,

[a]t certain times and in some areas, the mushrooms were naturally rare and hard to find. During the long Siberian winters, the more affluent tribesmen were able to store up supplies of the dried mushrooms in large quantities for winter consumption. The poorer individuals, none the less anxious to use the agaric, were often frustrated by the cost and limited supply of the plants. ${ }^{53}$

Summing up several existing studies of the subject one may conclude that there existed a certain "mushroom-eating hierarchy" of sorts. It appears that the fungi themselves were consumed by the elite, whether by shamans or

$\begin{array}{ll}52 & \text { Schultes } 1969 \\ 53 & \text { Ibid. }\end{array}$


tribal chiefs. The others, that is, the poorer folk were forced to drink the rich people's urine instead of getting a real mushroom in their mouth. ${ }^{54}$

The traditional (orthodox) Marxist reading of the Mukhomor-imbued urine topic had a lot to offer for the sake of proper and timely argument that was voiced fiercely during the Soviet period. As one scholar would formulate:

[t]hose poor bodies who do not have the financial ability to stock up on such expensive mushrooms usually hang around the houses of the rich on holidays, spying out the guests. When those come out to take a leak, the poor guys are ready with a wooden vessel to gather the piss and then drink it immediately while it still preserves the main narcotic properties of the mushroom. [...] Among the Koryak, the fly agaric is the rich people's treat, while the poor folk can only have their urine. When someone inebriated with the Mukhomor goes for a piss, many run up to him and guzzle his urine which makes them even more drunken than the one who actually ate the fly agaric..$^{55}$

54 See Bogoraz 1991. See Bogoraz's characteristic summation of the Chukchi Mukhomorinduced autochthon indigenous religious culture: "They say, why did you come here? Go home, go away. He replies 'I came from the dead people. Many people eat Amanita muscaria (Mukhomor) here and there. People from the Anadyr' region bring the Mukhomor. They address the Mukhomor as a deity before their meals ... Etc." See the original quote: “Говорят: 'Ты зачем пришед? Уходи, домой воротись'. Домой уходит, возвращается. Бывает разным образом; иной, правда, дышит, но без ума становится, так как при этом, должно быть, ему грезится, или что? Говорит: 'Я пришел оттуда, от мертвого народа'. Впрочем, также едят мухомор люди. Анадырщики привозят мухомор. Перед едой говорит, обращаясь к мухомору: 'К мертвому народцу увезли меня'. Действительно, он потом увозит. Погружается, обмирает; потом увозит, но лишь только душу. При этом имеющий внутреннюю боль совсем остается.... Действительно, от них с трех сторон: один возвращенный собакой, потом, во-вторых, самим сострадательным божеством, так что мертвое племя отвергает его, этот сообщает вести, в-третьих, мухомороед говорит...".

«... Те, кто не имеют материальной возможности запастись такими грибами, обычно околачиваются по праздничным дням у домов богачей, выслеживая гостей. Когда они выходят, чтобы помочиться, они живо подставляют под их струю деревянную посудину, чтобы собрать их мочу, которую они тут же жадно выпивают, так как в ней еще сохранились основные наркотические свойства гриба. [...] Мухомор у коряков-угощение богачей, бедные же довольствуются мочой последних; когда такой опьяневший от мухомора мочится, то к нему сбегаются многие и, выпив его мочи, пьянеют еще больше, чем сам наевшийся мухоморов.» (Lindenau 1983, 124-132). 


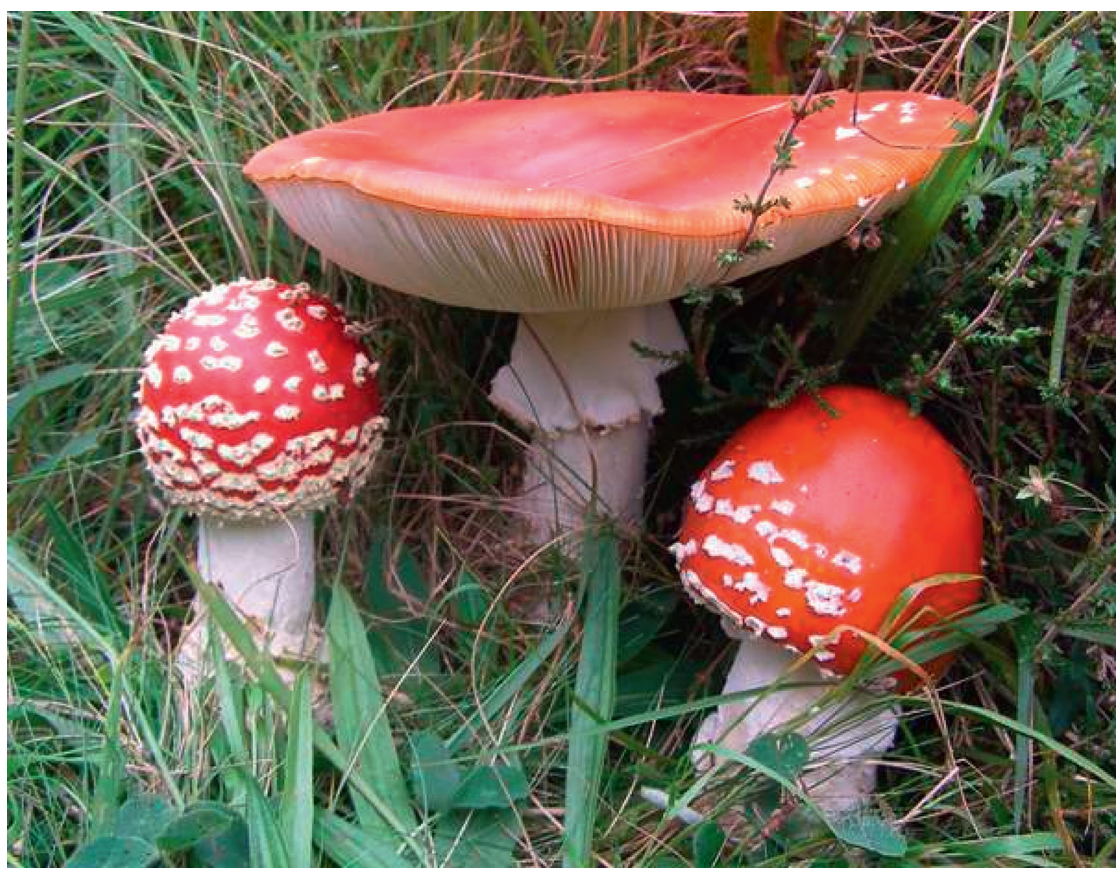

FIGURE 6 Amanita muscaria

REPRODUCED IN HTTPS://WWW.FIRST-NATURE.COM/FUNGI/AMANITAMUSCARIA.PHP

The "Mukhomor urine" of an intoxicated person appears to be a very meaningful subject for the Amanita muscaria practitioners in general. We can see that this urine of someone intoxicated with the Mukhomor is capable of inducing similar intoxication in another person who would care to drink it. This mushroom-imbued urine is considered to be only slightly less inebriating than a dose of the mushroom itself. An early account left by von Strahlenberg in 1736 depicts this remarkable practice of the Koryaks as follows:

[w] hen they make a feast, they pour water on some of these mushrooms and boil them. They then drink the liquor, which intoxicates them; the poorer sort, who cannot afford to lay in a store of these mushrooms, post themselves on these occasions round the huts of the rich and watch the opportunity of the guests coming down to make water and then hold a wooden bowl to receive the urine, which they drink off greedily, as having still some virtue of the mushroom in it; and by this way they also get drunk. ${ }^{56}$

$5^{6} \quad$ Furst 1976, 94. 
In 1755, Stephan Krasheninnikov remarked:

Aside from other things, the Mukhomor [cf. Fig. 6] is venerated by the settled Koryaks so much that the drunken are not allowed to pee on the floor. Instead, they gather the urine in crockery and then drink it, which makes them as crazy as those who ate the mushroom: this is because the land of the Koryaks does not yield the Mukhomor, so they have to get it from the Kamchadals. ${ }^{57}$

Not only the urine of others was drunk, but an individual might have further utilized and consumed his own urine, "often still warm," thus prolonging the action of the originally eaten mushrooms or renewing their effect several times. A drunken Koryak, Schultes observes, "may even carry his own urine with him on a reindeer trek to continue his intoxication as long as possible."58 It is an acknowledged fact that the Siberian tribesmen did not always drink urine because of economy or poverty (Schultes 1969).

Carl Heinrich Merck (1761-1799), originally from Darmstadt, was a RussianGerman medical doctor, geographer, and naturalist. He took part in BillingsSarychev expedition aimed at discovering and researching the North-Eastern shores of Russia in 1786-1792. Having studied the role of the Mukhomor-imbued urine among the Koryaks he supported the information already provided by Krasheninnikov:

The Mukhomor is used mostly by the Koryaks who consume it either fresh, as in this form its effects are stronger, or dried and rolled-up. They chew it for a short while and then swallow it. They are used to swallowing up to four dried mushrooms at a time. The inebriated Koryaks are being closely watched: firstly, in order to pick up anything that these madmen are spitting out, and secondly, in order to collect their urine which, according to some, has a stronger influence than even the fly agaric itself. Reindeer love mushrooms and get fat on them; they also get drunk from the Mukhomor. Koryaks mention another type of Mukhomor, the one that does not have white spots on their caps: this is the pale-colored

\footnotetext{
57 «В протчем у сидячих коряк мухомор в такой чести, что пьяному не дают мочиться на пол, но подставляют посуду, и мочу его выпивают, от чего также бесятся, как и те, кои гриб ели: ибо они мухомор получают у камчадалов, а в их сторонах не родится.» (Krashenninikov 1994, 110).

See Schultes 1969 .
} 
Mukhomor that they avoid consuming as it allegedly causes bouts of pain in the thighs. ${ }^{59}$

Expressly important for our subject is the continuous, well-established association between fungi and men, i.e. the anthropomorphic dimension of mushroom/human relationship. Numerous episodes in The Mythogenic Love of the Casts confirm that Peppershtein and Anufriev are always prone to see mushrooms as related to human bodies or even mighty humans standing by their own right. A recent British scientific mycological study reinforces the empirical link between the "fungal" and the "human" as embodied in the concrete physical shape that some mushrooms tend to assume. This includes, for example, a fungus named "G. britannicum", (cf. Fig. 7) which appears to be shaped quite like a human (Spooner, Henrici, Ainsworth 2015, 54-57). Its related kin "G. fornicatum" was initially known as "Fungus Anthropomorphus" because of its humanoid shape. English naturalist James Sowerby mentions a similarly marvelous mushroom in his text Colored Figures of English Fungi or Mushrooms (1799): "So strange a vegetable has surprised many; and in the year 1695 it was published under the name of Fungus Anthropomorphus, and figured with human faces on the head."

This anthropomorphic mushroom can easily bring back the memory of Sergei Kurekhin's widely celebrated idea of Lenin as a mushroom, as I will elaborate below. In the same vein, with regard not only to Koryaks but also to the Chukchi beliefs about spirits connected with Amanita muscaria, Vladimir Bogoraz notes the following:

The intoxicating mushrooms $[\ldots]$ are a separate tribe $[\ldots]$ They are very strong, and when they grow, their soft heads lift up heavy tree trunks and split them in two. A mushroom of this species grows through the heart

59 «Мухомором пользуются главным образом коряки, употребляя его либо в свежем виде, так как он крепче, или засушенным в свернутом виде. Они жуют его недолго и потом проглатывают целиком. Сушеных они привыкают проглатывать до четырех штук сразу. Одурманенных коряки охраняют, во-первых, чтобы подобрать то, что эти безумцы выплевывают, во-вторых, чтобы взять их мочу, которая, по их утверждению, действует значительно лучше самих мухоморов. Олени, которые любят грибы и от этого жиреют, также пьянеют от мухоморов. Коряки называют еще второй вид грибов, подобных мухомору, у которых нет белых крапинок на шляпках-беловатый мухомор, употреблять который они, однако, избегают, потому что это вызывает якобы сильные приступы с болями в бедрах.» (Merck $1978,92)$. 


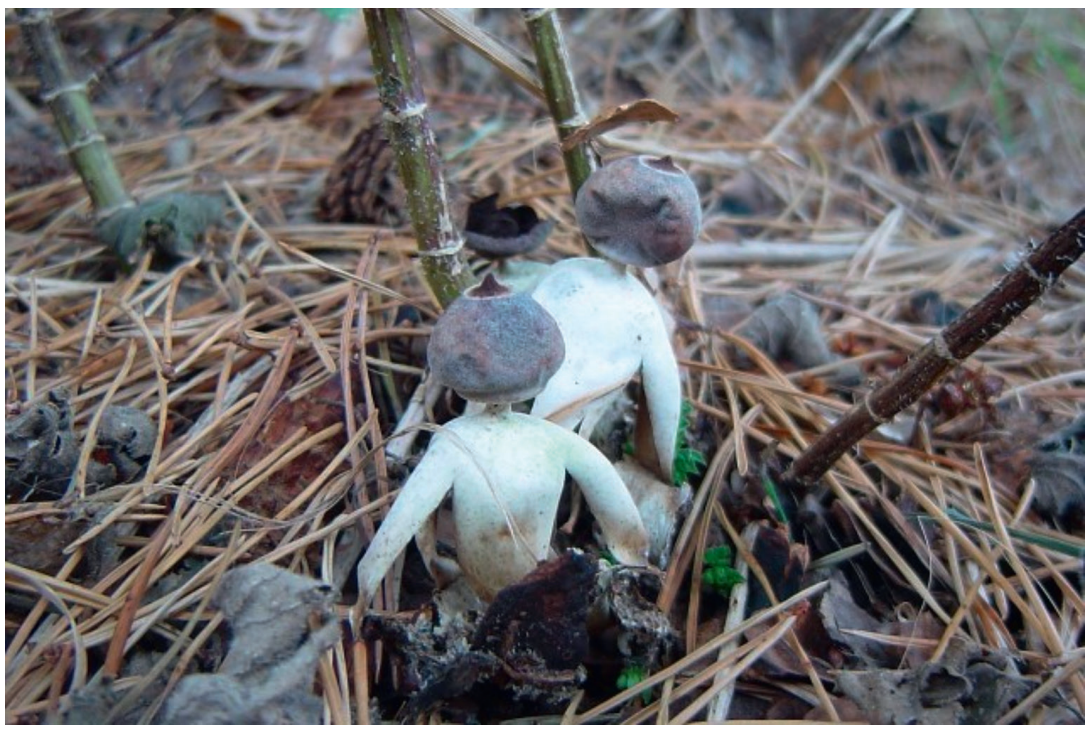

FIGURE 7 Anthropomorphic mushrooms

REPRODUCED IN SPOONER, HENRICI, AINSWORTH 2015

of a stone and breaks it into minute fragments. Mushrooms appear to intoxicate men in strange forms somewhat related to their real shapes. One, for example, will be a man with one hand and one foot; another will have a shapeless body. These are not spirits, but the mushrooms themselves. The number of them seen depends on the number of mushrooms consumed. If a man has eaten one mushroom, he will see one mushroomman; if he has eaten two or three, he will see a corresponding number of mushroom-men. They will grasp his arms and lead him through the entire world, showing him some real things and deluding him with many unreal apparitions. [...] They delight in visiting the places where the dead live. The spirits of the mushroom often play practical jokes on a person under their influence, but they also guide him to other realms or guard him from harm in this world. ${ }^{60}$ 


\section{The Mythogenic Love of the Castes as a Mushroom-Eating Epic Narrative}

As I have already noted, the "mushroom topic" seems to be at the core of Mifogennaia liubov' kast as a literary text. As we learn from the novel, the psychotropic mushrooms help "transform" the Communist Dunaev into a sort of "new species"61, namely a mythogenic wizard and many-faced war hero. Dunaev's hallucinogenic battle that he wages alongside a most powerful enigmatic magician named Poruchik Kholeny ["First lieutenant 'Sleek"] offers an extension of the "communal Russian being" exercised by the Noma-practices of the Inspection Medical Hermeneutics.

The list of "dramatis personae" featured in the novel is extremely complex and long. Some of the characters operate on Dunaev's side while others trickily oppose him. The main "active characters" in the novel are Dunaev himself ("partorg" - party organizer) and the aforementioned First Lieutenant Kholeny. Dunaev, the mighty warrior in the imaginary War, engages in mushroom-eating "forest practices" and proceeds to fight the "dark forces", siding with the "bright ones" in order to help achieving victory in the Great War.

The "infernal" hallucinogenic beings (so-called half-life/undead/"nechist") are at times sided with the German Nazis and their various collaborators. Among others are the so-called "Sviaschenstvo" (the Holy Ones), also known under the additional surrealistic/psychedelic names of "Roly-polies", "Sturdy buggers", and “Greenhorns” (“Неваляшки”, “Крепыши”, “Пострелы”).

The universe of "enemies" and "our own kin" is structured according to fairytale storytelling patterns. Russian and Soviet folklore/literary characters represent various natural forces, whereas the characters of various European children's books side with the Nazi Germans. Hence, the 'Gingerbread Man', the 'Log Cabin', 'Geese-Swans', 'Self-setting Tablecloth', 'Old Speckled Hen', 'Buzzy Wuzzy Fly', 'Gene(Genius) the Crocodile', 'Cheburashka,' 'Russian Santa Ded Moroz' ('Колобок', 'Избушка', 'Гуси-Лебеди', 'Скатерть-Самобранка', 'Курочка Ряба', 'Муха Цокотуха', 'Крокодил Гена(Гений)', 'Чебурашка', 'Дед Мороз') are somehow opposed by 'Karlsson-on-the-Roof', Goodwin the 'Wizard of Oz' (aka 'the Grocer') ('Бакалейщик Гудвин'), Ellie Smith/Dorothy Gale ('Элли-Фея Убивающего Домика'), Totoshka (Little Toto the puppy), Peter Pan ('Петька Самописка'), 'Hurvínek', ('Гурвинек'), 'Jurgen von Cranach' 61 What he becomes is actually no live being but rather an 'Unwesen' as Germans would call
it. Or nezhit' ('half-life'/'undead'), as Russians would rather label it. 
('Юрген фон Кранах'), Alice of the Wonderland, Winnie the Pooh, the 'Blue' Mary Poppins, etc.

This scheme is supplemented by two special narrative figures of the 'Writer-journalist' and the 'Camera-man' ('Корреспондент' and 'Кинооператор'). The Journalist/Writer (partially impersonated by Murzilka, a cartoonish character behind the popular eponymous children's magazine ${ }^{62}$ ) is de facto narrating the entire story of Dunaev the Warrior. Both the Journalist and the Camera-man may seem to represent two possible "ends" or even "deaths" of Dunaev. There are some more mysterious characters like the mighty anthropomorphic river-human called 'Don' (the authors also stress that this odd character visually resembles Stalin himself). Another character who replaces the First Lieutenant as Dunaev's spiritual mentor is called "Immortal", a patient from the Kashchenko psychiatric hospital ('Бессмертный старик из Кащенко'), and yet one another who is referred to as 'Doctor Arzamasov'. The latter fulfills his medically hermeneutic function by "explaining" to Dunaev the psychedelic mechanism of his forest fungal delirium. This doctor is deviously sided with the ambivalent darker forces and is alternately called "Doctor Aybolit" or 'Bo-Bo'.

The early chapters of the novel were conceived by Peppershtein and Anufriev within their group starting from the late eighties and read aloud at the group's collective gatherings long before they finally appeared in print with 'Ad Marginem Publishers' of Moscow. They correspond to the concept of Noma which was introduced in 1988 by the members of the group (Peppershtein 1993, 8-17).

Noma stands for a "psychological space of perception"63 that functions as a certain complex of language realizations emerging at different stages of communal discussions. Remarkably, for this artistic group, "culture" generally entails a system of family relations of various sorts. In the Ancient Egyptian culture, the term Noma refers to the "collective sacred body" alluding, according to Peppershtein, to the fate of the god Osiris. A nome (from Greek vouós, 'district') functioned as an administrative unit of Ptolemaic Egypt. This term allegedly derives from the mythical narrative about the pieces of Osiris's body that were buried in various respective districts of the country, thus allowing for its collective/discoursive/administrative subdivision. The number of Osiris's nomes varies, depending on the available accounts, between fourteen

62 On the "real" side of this character, by his didactic (and dialectic) role, Murzilka appears to be an anti-trickster, an emphatically positive character whose job is actually fighting and disabling tricksters. See the general cultural context described in Lipovetsky 2010. 
and forty-two. The two versions of the Jumilhac Papyrus mention fourteen pieces collected by Isis in twelve days corresponding to the duration of the festival of ploughing (Guilhou 1998, 19-26). According to Diodore of Sicily $(1,21,2)$, Typhon, a co-conspirator, "cuts his victim's body into twenty-six pieces." The "sacred geography of Edfu" mentions as many pieces as there are nomes, being forty-two (Guilhou 1998). Noma as a group is therefore nothing but a collective body of creative thinking conscience, something quite different from, say, Artaud's well known concept of the Body without Organs. ${ }^{64}$ Peppershtein's group certainly has organs, and these organs actively think.

To a certain degree, Peppershtein's practical poetics might resemble those of Daniil Kharms, the founder of the "ultimate" Russian Avant-Garde group called oвERIU. Both Kharms and Peppershtein appear to be "mentally injured," vulnerable and fragile sociopaths of sorts. They share a great deal in common, especially with Kharms's output as an artist in mind. We should not fail to mention here that the Bolshevik revolution and subsequent catastrophic events in Russia challenged and reshaped many conventional assumptions about corporeality, physical perception of time, and temporality. The early Russian avant-garde was equally informed by the utopian energies of the Revolution and by the newest developments in European philosophy and art that also questioned and critiqued the traditional understanding of corporeality, art, and time. Being the last heirs to the "heroic" Russian avantgarde, Kharms's circle of writers should be regarded as a historic antecedent to Peppershtein's Medical Hermeneutics/“Noma-circle." ${ }^{65}$ In a certain way they share the Futurists' obsession with the end of history as we know it (cf. Maiakovsky with his famous motto "We'll ride the Nag of history to death!"). Possibly, Kharms and Peppershtein together bring this trend to its logical conclusion and consumption. In a similar way, Antonin Artaud was drawing his artistic perception of corporeal temporality from Charles Baudelaire's concept of a hieroglyphical tangible dream to be found in Les paradis artificiels ("Ce rêve, que j'appellerai hieroglyphique"). This "dream" might be proven to have had a narcotic/hallucinogenic nature in its source. One can maintain that Artaud perceives flesh/body-hieroglyph as an archetype of temporality. As Artaud puts it in "Sur Le Théâtre Balinais" and in some of his later works, a hieroglyphical dreamy object ("oneiric") stands for the ineffable higher reality of existence and makes it possible to destroy the mundane time-flow of

\footnotetext{
64 On the relation between Artaud and the later Russian Avant-Garde, see Ioffe 2013a.

65 On the well-grounded corresponding potential relation see Ioffe 2006 where the stiobby and ludic nature of Kharms and OBERIU is explored.
} 
everyday life. In this context, human flesh and human hieroglyph are initially grasped as unknowable noumena of the Kantian Ding an sich. The forthcoming research should consider these international Avant-Garde traditions in terms of the mystical temporality of performance and the larger debate on the modern "body," identity, and subjectivity.

I ought to emphasize, moreover, that the Great War surrealistically depicted by Peppershtein and Anufriev is nothing short of a fungal hallucinogenic affair parscriptu, being a natural outcome of the psychoactive intoxication that the leading characters are subjected to in their text. It would therefore be worthwhile to try and single out a number of the most relevant fungi-related textual episodes. These fragments attest to the special means the authors employ to narrate the hallucinogenic blend of the human body and that of a mushroom. Fungi seem to accompany humans in their hallucinogenic quest for truth in the wide world. The new materiality deriving from this pursuit transcribes the plant into the reality of the page and vice versa. ${ }^{66}$

The first encounter with a fungus, probably a Mukhomor, occurs in one of the early chapters: "Moss was under his feet. Dunaev stopped under a fir-tree. He was clutching a mushroom in his hand and going to look at it closely in order to find out if it can be eaten." 67 Then more encounters take place where several types of psilocybin mushrooms are merged together:

Dunaev was walking, brushing against the tree trunks. He wasn't picking any more mushrooms when something suddenly seemed to call to him through the mossy fog: "we are here!" Instinctively Dunaev rummaged under the tree, found some slippery nubbins and realized within a moment that that was a handful of tiny mushrooms like morels. He opened his mouth and put in the spoils. He chewed on and found the taste pleasant. He then discovered a whole patch of these small mushrooms, quelled his hunger and sat down under the tree to catch his breath. Five minutes later he felt dizzy. Everything started spinning, and suddenly Dunaev realized that he was lying on a flat, sparkling dais. ${ }^{68}$

66 On related matters, see Ford 2014.

67 «Под ногами был мох. Дунаев остановился под елкой. Он держал в руке гриб и собирался рассмотреть его внимательно, чтобы узнать, можно ли его съесть.» (Peppershein, Anufriev 1999).

68 «Дунаев шел, задевая за стволы. Он уже не собирал грибов, но вдруг что-то сквозь моховой туман как будто прокричало ему: 'Мы здесь!' Инстинктивно он нашарил под деревом какие-то склизкие комочки и в следующий момент понял, что собрал горсть мелких грибов, похожих на сморчки. Он открыл рот и отправил туда 
The first account of a proper hallucinogenic trip that the partorg experienced in the Russian forest unfolds as follows:

The partorg lay spread-eagled on the rotten grass at the foot of the tree, unmoving, with his eyes closed and his limbs outstretched, like a corpse. [...] His eyes were brimming with meaningless tears, his lips spattered with vomit. Eating the invisible speaking fungi was insanity: hallucinations ended up with vomiting which resulted in exhaustion. He must have lost his consciousness or maybe sank into a morbid sleep. ${ }^{69}$

Then there follows the key episode that narrates Dunaev's major hallucinogenic experience caused by the most powerful psilocybin:

Lagging behind the First Lieutenant, Dunaev was smoking his roll-up joint when he noticed another mushroom that looked like a morel. Speaking frankly, it looked more like brains, but Dunaev tried to repel that thought as he picked it. Holding the mushroom in his hand, Dunaev suddenly felt a surge of vigor. All around grew dark as if he just inhaled pure oxygen. He hurried forward to catch up with the First Lieutenant, handed him his find and earned praise for discovering a rare and precious specimen of a Dum mushroom.... "These Dum ['Thought'] mushrooms only grow on the graves of the drowned, feeding on them. They also grow on the graves of somnambulists but nowhere else," he explained with a wink. Then again the First Lieutenant charged forward and disappeared while Dunaev sat down on a hillock and noticed something dark and looming in the thicket. Dunaev came closer and discovered an old hut ${ }^{70}$ covered with moss, black and half-ruined. Dunaev peered inside. It was dark and empty, but right in the center there was a big mushroom with a short

собранное. Пережевал-вкус приятный. Разыскав целую полянку таких грибков, он утолил голод и присел под деревом отдышаться. Через пять минут ощутил головокружение. Все завертелось, и неожиданно Дунаев осознал, что лежит на ровной, искрящейся площадке.» (Peppershein, Anufriev 1999).

69 «Распластанный в гнилой траве у подножия дерева, парторг лежал неподвижно, с закрытыми глазами, раскинув руки и ноги, как мертвец. [...] На глазах бессмысленные слезы, на губах рвота. Поедание невидимых говорящих грибов оказалось безрассудным поступком—галлюцинации завершились рвотой, которая привела к бессилию. Он то ли потерял сознание, то ли забылся обморочным сном.» (Peppershein, Anufriev 1999).

70 This mushroom in a hut is essentially a "genre scene" of Vladimir Lenin in "Razliv" as per Sergei Kuriokhin's theory, see below. 
white stem and a swollen white sponge like a poplar's crown on its top. Reaching out, Dunaev felt warm. Still, he picked the mushroom, and its whiteness became tinted with purple. Oblivious of the First Lieutenant's words, Dunaev was enthralled by the beauty of the mushroom. [...] Holding it in his hand, Dunaev leaped on a tree stump and started chewing on the porous, crunchy and fragile flesh of the mushroom. ${ }^{11}$

The suggestive fungal topic in Russian literature looks quite abundant. Hence Medical Hermeneutics' obsessive preoccupation with mushrooms bears multiple referential parallels in Russian and world literature. There are a few narratives that can be compared to, say, the already mentioned "The Purple Pileus" by H.G. Wells. Therein we find a typical literary description of a "magic mushroom" that was certainly familiar to both authors of Mifogennaia liubov' kast. It is worth quoting the respective fragment in its entirety in order to clarify its potential influence on the authors of the novel in question:

He thought of the canal he had just crossed, and doubted whether he shouldn't stand with his head out, even in the middle, and it was while drowning was in his mind that the purple pileus caught his eye. He looked at it mechanically for a moment, and stopped and stooped towards it to pick it up, under the impression that it was some such small leather object as a purse. Then he saw that it was the purple top of a fungus, a peculiarly poisonous-looking purple: slimy, shiny, and emitting a sour odour. He hesitated with his hand an inch or so from it, and the thought

71 See: «... Отстав от Поручика, парторг курил самокрутку и тут увидел еще один гриб, похожий на сморчок. Откровенно говоря, он походил больше на мозги, но Дунаев гнал от себя эту мысль, срывая его. Он ощутил внезапную бодрость, держа его в руках. Все вокруг потемнело, как от глотка чистого кислорода. Быстрым шагом он нагнал Поручика, вручил ему находку и удостоился похвалы за редкий и ценный экземпляр Дума./ - Думы-грибы растут только над утопленниками, ими кормятся. Еще только на могилах умерших лунатиков растут, больше нигде,пояснил Холеный и подмигнул./ Опять Поручик исчез впереди, а Дунаев присел на кочку и заметил в чаще что-то темное, возвышающееся. Приблизившись, Дунаев обнаружил старый шалаш, покрытый мхом, черный и полуобвалившийся. Дунаев глянул внутрь. Там, в полутьме, было пусто, но в самом центре рос большой гриб, на короткой белой ножке, от которой вверх тянулась, как крона тополя, распухшая белая губка. Протянув руку, Дунаев ощутил тепло. Но он сорвал гриб, причем белизна того приняла несколько фиолетовый оттенок. Он забыл о словах Поручика, покоренный красотой гриба. [...] Дунаев, держа гриб в руке, запрыгнул на пень и стал жевать губчатую, хрустящую, хрупкую мякоть гриба.» (Peppershein, Anufriev 1999). 
of poison crossed his mind. With that he picked the thing, and stood up again with it in his hand. The odour was certainly strong-acrid, but by no means disgusting. He broke off a piece, and the fresh surface was a creamy white, that changed like magic in the space of ten seconds to a yellowish-green colour. [...] They were wonderful things these fungi ... ${ }^{72}$

Michael W. Beug from the North American Mycological Association shrewdly observes that the famous masterpiece of English literature, Alice in Wonderland "[...] was written by Lewis Carroll after he had experimented with Amanita muscaria, and that the changes in size and time perception described in that book are characteristic effects of the mushroom intoxication." (Beug 2006). The parallels between Alice in Wonderland and Mifogennaia liubov' kast seem to be quite intricate and far-reaching. This might constitute a separate topic for a future study. Many Russian authors before Peppershtein and Anufriev left a handful of narratives recounting their mushroom-hunt. In this context we should not fail to mention S.T. Aksakov's "Griby" ["Mushrooms"], filled with valuable mycopoetical observations, and especially Mikhail Prishvin's "Staryi grib" ["Old Mushroom"]. The latter includes the following semi-hallucinogenic quote:

Not without a few groans I had to get down to my old knees and lie on my belly. Out of necessity, I had to bow to the russula. And the birds! The birds were singing as if nothing happened. It all turned out so neat and handy that as I lay down on my belly my parched lips pressed upon the cold lips of the mushroom ... ${ }^{73}$

There exist many fascinating creative parallels between the Russian Boroviktype "white mushrooms" (i.e. Boletus edulis known also as cep, porcino or porcini) and the human race in popular vernacular etymology and names. In 17th19th centuries there existed certain semantical contrapositions between griby ['mushrooms'] and guby ['human lips']. The edible mushrooms ("griby-proper") were semantically opposed to various nameless toadstools and Amanita phalloides (known also as deathcap). It is interesting to note that the phallic shape of

72 Wells (1966).

73 «Покряхтел я, покряхтел, опустился на свои старые колени и лег на живот. По нужде, говорю, поклонился я сыроежке. А птички-то! Птички играют свое. Так это ладно пришлось, что когда я лег на живот, то мои запекшиеся губы сошлись как раз с холодными губами гриба ...» (Prishvin 1983). 
a young deathcap fruitbody, emerging from its volva, gave rise to its specific Latin epithet phalloides, something that reinforces the provocative similarity of the human body and fungi. The Russian "white mushroom" is used to refer to their opposition to "black mushrooms" or "dogs' fungi" (sobachie griby). ${ }^{74}$

A Modernist poet Marina Tsvetaeva in her turn compared men to (white) mushrooms in her 1920 poem (from the collection Lebedinyi Stan [The Demesne of the Swans]) extending this comparison to Mother-Earth/Russia that gives birth to her anthropomorphic children-fungi.

Oh, my dear little mushroom, my baby white Lactarius

That's the voice of (Mother) Russia stumbling in the field,

Help me, for I am too shaky on my feet,

My eyes are clouded by blood iron-ore

There are open wounds to the left

And bloody wounds to the right,

And each screaming: Mama. ${ }^{75}$

Tsvetaeva further plays with the poetic comparison of the Russian white mushrooms to the White Guard counter-revolutionary fighters who might transform into their mortal enemies - the Red Army soldiers:

All lying next to each other: can't divide them.

Can't tell them apart: they all look like soldier warriors.

Used to be white, blood turned you red.

Used to be red, death turned you pale white. ${ }^{76}$

74 «B XVII-XIX веках существовали противопоставления, утерянные современным русским языком и частично сохранившиеся только в отдельных говорах: грибы-губы (губы-грибы, идущие только в засол, или грибы-белые, губыгрибы вообще, или губы-грибы, имеющие вид наростов на дереве, трутовики); грибы-грузди; грибы (съедобные)—собачьи грибы, или поганки (ядовитые, кроме мухомора).» (Merkulova 1967).

75 «Ох, грибок ты мой, грибочек, белый груздь!/ То шатаясь причитает в полеРусь./ Помогите-на ногах нетверда! Затуманила меня кровь-руда!/ И справа и слева/ Кровавые зевы,/ И каждая рана:-Мама!» (Tsvetaeva).

76 «Все рядком лежат-/ Не развесть межой./ Поглядеть: солдат./ Где свой, где чужой? Белый был-красным стал:/ Кровь обагрила./ Красным был-белый стал: Смерть побелила.» (Tsvetaeva). Worth pointing out that Tsvetaeva also plays upon the metaphorical line of “белые грузди” “белогвардейцы” in her earlier poem “Белогвардейцы! Гордиев узел ...” (1918) and evidently refers to Russian folklore as the contextual source of inspiration: “Белогвардейцы! Белые грузди/ Песенки русской!” 
All in all, Tsvetaeva was the first Russian major Modernist author who not only (mytho-) poetically merged mushrooms with humans in this highly influential poem, blurring the boundaries between the two species, she had provocatively hinted at turning a "white" (man/mushroom $)^{77}$ into a "red" (man/mushroom). The most typical Russian "red mushroom" as opposed to the white Borovik ${ }^{78}$ is of course a hallucinogenic dangerous Mukhomor. In Tsvetaeva's poem, the pure White Mushroom, the pristine white Lactarius is traumatically transformed into the bloody/poisonous amanita muscaria of sorts, a deadly fungus reddened by the Civil War. In other words, the bloody war is turning white Borovik-people into red-headed Mukhomor-men.

Peppershtein and Anufriev seem to be subversive readers of Tsvetaeva's poem, embodying her metaphor at a notable scale in Dunaev's Mukhomor episodes of the novel, implicitly corresponding to the common subject of the sacrificial, "Russia-redemptive" combat of the patritic/civil War, just as it happens in her modernist verse.

Vladimir Soloukhin's Tret'ia Okhota. Griby [The Third Hunting. Mushrooms] (1967) also offers some insightful observations that further reveal the anthropomorphic element present in a mushroom:

Of all the forest gifts, at least in our forests, only mushrooms can be honored as a real hunting trophy that is equal or almost equal to game and fish [...] Some say that the king of mushrooms is a Boletus. I tend to agree, but personally I value above all the Lactarius delicious, commonly known as the Saffron milk cap or Red pine mushroom. The "ryzhik" of the pine forest, as big as a tea-saucer or as small as one kopeck, the "ryzhik" that exudes bright orange juice when cut, the "ryzhik" of Vologda, the "ryzhik" of Viatka, the "ryzhik" whose name graces ginger kittens, puppies, and even red-haired urchins ...79

77 Aside of a standard white-Boletus it could be another "member" of the Boletaceae, e.g. a leccinum ('подберёзовик' оr 'подосиновик').

78 Mushroom-related family denominations are quite widespread in Russia(n). Families like Gribov, Grib, Griboedov, Gruzdev, Syroezhkin, Podosinov, Borovikov, (also the famous tvBorovik), Ryzhikov (e.g. the last Prime minister of USSR), etc., are very well known.

79 «[..] из всех лесных даров, по крайней мере в наших лесах, только грибы могут удостоиться высокой чести и называться предметом охоты наравне или почти наравне с дичью и рыбой. [...] Одни говорят, что царь грибов все-таки боровик. Пожалуй, соглашусь, но, соглашаясь, для себя на первое место ставлю сосновый, или боровой, рыжик. Рыжик сосновый, рыжик величиной с чайное блюдце, рыжик величиной с копейку, рыжик, из которого на разрезе льется яркий оранжевый 
Aside of this, one might also recollect Nabokov's personal account, as sensitive as it is suggestive, of "mushroom hunting" in his nostalgic "Speak, Memory," and most importantly, Sergei Kurekhin's surrealistic steb-scented TV-sketch

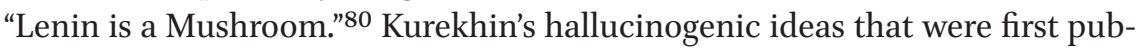
licly expressed as early as in 1991, which might haveadded some vivid scenery to Mifogennaia liubov' kast which was still in progress at that time. As countless critics have already observed, it was none other than Aleksandr Solzhenitsyn who served as a conceptual source of Kurekhin's surrealistic stunt. Subsequently it had also influenced Peppershtein and Anufriev who certainly could have read Solzhenitsyn on their own accord and notice the affinities between Lenin and mushrooms emphasized by this author. In Krasnoe koleso [Red Wheel]: Mart semnadtsatogo [The March of the Year ' 17 ], book 2, Solzhenitsyn relates:

Lenin wore his head as something that was both precious and sick. That apparatus intended for instant arrival at infallible decisions and finding conclusive arguments [...] This must be the way mould grows in a massive chunk of flesh: bread, meat, mushroom - with a bloom of greenish film and thin cords protracting deep inside, as if all were still intact and yet already tainted and irremovable.. $.81^{81}$

Somewhat later he makes an even more explicit connection between Lenin and mushrooms:

Yes, the horse surely felt it was the biggest beauty there ... But the lady rider sat astride, looking either serene or sad, staring steadily at the road that was sloping downwards, and never glanced either at the obelisk or the badly dressed mushroom, squashed on the bench in his black bowler.

сок, [...] рыжик вологодский, рыжик вятский, рыжик, именем которого называют рыжих котят, рыжих щенков и даже рыжих мальчишек [...]» (Soloukhin 1986).

8 o On this affair see series of stimulating studies by Alexei Yurchak (2011; 2013; 2015).

81 «... голову носил Ленин как драгоценное и больное. Аппарат для мгновенного принятия безошибочных решений, для нахождения разительных аргументов ... Вероятно, как прорастает плесень в массивном куске живого-хлеба, мяса, гриба,-налётом зеленоватой плёнки и ниточками, уходящими в глубину: как будто и всё ещё цело и всё уже затронуто, невыскребаемо ...» (Solzhenitsyn 2008). 
And he sat motionless, examining her face and the black strand of hair peeking from under her hat. ${ }^{82}$

By the end of the Perestroika eighties, both Kurekhin and Peppershtein/ Anufriev probably accessed and read this text via the original "Tamizdat" edition published by YMCA-PRESS (Vermont-Paris, 1983). For the sake of argument it appears quite important to mention this original connection as long as the Communist ("partorg") Dunaev can be perceived but as a small replica of Lenin. Dunaev plays the role of a magical defender of the Russian land, a "small mighty Lenin"(alias Kolobok) of sorts, the one who manages to wage a hallucinogenic battle and eat mushrooms at the same time.

Another powerful crypto-influence related to the Lenin/fungi theme may have proceeded from the phantasmagoria-scented surrealistic drama written in 1913 by Velimir Khlebnikov and called Gospozha Lenin [The Mistress Lenin or The Mistress of Laziness]. This suggestive text was originally not related to Lenin but to the androgynous daughter of laziness; however, eventually Khlebnikov changed his attitude, adding some initially absent "political" connotations. ${ }^{83}$

Khlebnikov might have intended to stress the fungal spore-based "foreignness" of "Lenin"/Marxism on the Russian soil as long as the term Lenin, aside from the "laziness" topic, represented also a certain Lehnwort (from entlehnen) - i.e. a kind of a loanword, a word/term deviously "lent" to another culture. One must not overlook the widely acknowledged fact (which was familiar also to the mass media in the Tsarist days) that Germany generously funded Lenin's various activities and actually "lent" him to Russia or re-planted him on its soil by transporting his spurious "mushroom" body inside a special "sealed coach." ${ }^{84}$ The standard definition of a "sporous body" that might have allegedly pertained to Lenin as an anthropomorphic mushroom is tightly connected to the very $(\mathrm{t})$ issue of fungal spores.

82 «... Да тут главной красавицей сознавала себя лошадь.... А всадница сидела невозмутимо или печально, смотрела только перед собой под уклон дороги, не покосилась ни на обелиск, ни на дурно одетого, внизу к скамейке придавленного, в чёрном котелке гриба. И он просидел, не шевельнувшись, разглядывал её лицо, чёрное крыло волос из-под шляпы.» (Solzhenitsyn 2008).

83 «На мелкие земельные владения/зар<н>ицею лени/оглавила госпожа Ленин/в Ряве она мною дана./Луч из будивремен из Будимира/сверкал [по] как чернила под пером/Велимира/А Ленин оглавил разложен<ие $>$ ппростр<анства $>$ России торг и труд в/их мелкие единицы.» (Quoted via N.N. Pertcova's chapter, “Osnovy mirovospriatia Khlebnikova" in her Motive - Topic — Text, an unpublished book-manuscript).

84 Cf. Wiegrefe, Altenhöner, et. al, Lenin und der Kaiser (December 18, 2007); also see Ioffe, Russian Experiment in Arts, forthcoming. 
These, as we know, are produced by all sorts of bacteria, but also by fungi. ${ }^{85}$ In this respect, the fungal image of Lenin can be associated with a certain kind of aggressive bacterial spores that function at the dormant stage in the "bacterial life cycle" intended to preserve "the bacterium through periods of unfavourable conditions." ${ }^{86}$ The less favorable conditions for Lenin-the-Fungus ${ }^{87}$ had to do with his pre-revolutionary persecution and forced emigration. It might be worthwhile to underline that "many bacterial spores are highly durable and can germinate even after years of dormancy." 88 Lenin sprang forth after years of his conspiratorial dormancy as a powerful Bolshevik revolutionary fungus working out of his mycelium that took the shape of an armored car (bronevik), should we follow Kuriokhin's surrealistic stiobby narrative. Lenin might have been originally born as a human, but this must not necessarily contradict Kuriokhin's theory since among the fungi, spores serve a function analogous to that of seeds. Lenin might have been a fungus who was erroneously born out of the human seed generated by his venerable parent Il'ia Ulianov. I follow this story up in such detail because I believe that both Peppershtein and Anufriev were actively parodying Kuriokhin's ideas about Lenin's biological nature when creating the image of the partorg Dunaev devouring hallucinogenic mushrooms, at times almost turning into a mushroom (aside of becoming 'Kolobok') himself, blurring the boundaries between the human body and the flesh of fungi. ${ }^{89}$

Generally speaking, the attitude of the Medical Hermeneutics group towards mushrooms differs from that of Sergei Kuriokhin in the sense that Moscow conceptualism has usually tended to add a greater degree of deadly "romantic metaphysics" to its objects of "art" 90 while St. Petersburg's (Leningrad Rock Club) version(s) remained more "faithful" to the traditional carnivalesque canvass of Russian Stiob per se. To put it plainly, there is much less of "laughter" in Medical Hermeneutics than in Kuriokhin's dealings with "all the things fungal".

85 More technically speaking, fungal spores are produced by myco-fungi, while bacteria produce endospores.

86 Encyclopedia Britannica.

87 Also 'Lenin-the bacteria'.

88 See Encyclopedia Britannica, Ibid.

89 There is apparently a popular tradition behind this fusion. One could recollect, for example, the name of the colonel Petrenko (Iurii Kuznetzov), the head of the Homicide department as depicted in the popular TV series Ulitsy razbitych fonarei [Streets of broken lanterns]. Petrenko routinely goes by the name of Mukhomor among the members of his group.

90 Consult the well-known essay by Groys on the subjects of metaphysics and romanticism inherently characteristic for Moscow conceptual school. 
Medical Hermenutical "stiob" remains more implicitly tragic than that of Kuriokhin that was rather focused on parodic "entertainment" as broadcasted to the millions of viewers by the Soviet First TV Chanel of the 'decomposing' Perestroika days (May 1991). ${ }^{91}$

Aside from Solzhenitsyn and Kuriokhin, there is a mushroom picking scene in Book III of Pan Tadeusz by Adam Mickiewicz that presents one of the most famous passages in Polish national literature ("Grzybobranie"). It was probably known to the authors of the Mifogennaia liubov' kast. In addition to that, in his Paris lectures, Mickiewicz narrated general Kopeć's recollections of his Siberian exile where he mentioned the consumption of hallucinogenic mushrooms as well (Mickiewicz 1865, 220).

It appears possible to surmise that Peppershtein and Anufriev landed on the very rich and intertextually loaded cultural soil of multi-national consummation of various types of mushrooms. Their "mushroom affair" presents a unique case of fulfilling one of the very basic methodological principles their artistic group was based on, as it was first analytically coined by Boris Groys. Mushrooms offer their best to deal with reality as if it had an infinite plenitude of possibilities, hermeneutical and medical included. The "rigorous overinterpretation" which seems to be so precious to the Medical Hermeneutics finds its refined realization in the fungi-induced scenes of the first volume of Peppershtein and Anufriev's novel. One can efficiently associate this with the extremely rich tradition in both ethnobotanical (Wassons, Schultes, Heim, etc.) and literary (Aksakov, Wells, Soloukhin) realms. Kuriokhin's surrealistic ideas based on Solzhenitsyn's narrative and its reference to the anthropomorphic nature of mushrooms obviously influenced the final crystallization of the published text of Mifogennaia liubov' kast as well. Both Kuriokhin and Medical Hermeneutics have paid exquisite homage to the indigenous brand of Russian irony known as steb. This topic has been profoundly researched in scholarly texts by Alexey Yurchak, Mark Yoffe, and Michael Klebanov. ${ }^{92}$ The question of whether Medical Hermeneutics in general and Mifogennaia liubov' kast in particular should be considered as a primarily stiobby phenomena deserves a special study. My preliminary answer is yes, this text has to do a lot with Russian stiob in folio.

Another influence embedded in the novel's text comes from the fellow conceptualist Moscow group called "The Mukhomors." This highly suggestive and provocative project was established in 1978 and involved artists such as Sven

91 See Yurchak 2o11.
92 On this See Yurchak 2006; Yoffe 2013, 207-225; Klebanov 2013, 227-253. 
Gundlakh, Konstantin Zvezdochetov, and the brothers Mironenko along with several others. Many of their famous works depict Amanita muscaria, and one is famously entitled "Ty nuzhen miru, Mukhomor" [The World Needs You, Amanita muscaria] (1980).

According to the group, "The people of Amanita muscaria dwell in the forests, on the hills, and in the meadows. They traverse the seas and the air. It is a brave and proud nation. Their bodies and faces are beautiful, tan and pale."93

Amanita muscaria also occupies a notable stiobby/ironic place in the contemporary art of Vasily Lozhkin-a prominent Post-Soviet Russian popular artist who created a unique series of mukhomor-related paintings.

The Amanita muscaria imagery has also been widely explored by two Conceptualist artists of the somewhat older generation, Igor' Makarevich and Elena Elagina. Their most notable creation was the crossbreeding between a suggestive reproduction of Tatlin's Tower and a huge sculptural Mukhomor (Degot, Zakharov 2005). Their monumental artistic project "Pagan" (2003) widely explores the amanita muscaria theme.

\section{Conclusion}

Mythographically centered ritual conceptions concerning psychoactive mushrooms that have been present profusely in many traditions of human culture should be considered unambiguously relevant for the purpose of "strong/close" reading of the contemporary conceptualist narrative describing the Great War with the Partorg Dunaev as its main combatant protagonist. The history of the Soviet "Great Patriotic War" as animated by Peppershtein and Anufriev emerges from the dark visionary world as an effort to narrate the major "strategic foci" of the famous battlefield events in the conceptualist, experimental, and most of the time proudly hallucinogenic and surrealistic ways. Every remarkable segment of the history of the Great Patriotic War acquires a virtual counterpart invented by hallucination-like conscience dominating this intriguing piece of fiction.

At the same time, the very topic of mushroom-human relations brings forth the idea of "new materiality" in culture ${ }^{94}$ as it is explicated in the text

93 «Мухоморы живут в лесах, в горах и на лугах. Мухоморы бороздят морские и воздушные просторы. Это смелый и гордый народ. Тела и лица у них красивые, смуглые и бледнолицые.» (Mukhomor 2010).

See further discussions in Berger 2009. 
of the novel. The psychedelic motive of Mifogennaia liubov' kast represents the conceptualist view of various modes of embodiment ${ }^{95}$ where the existing perception of imagined corpora blends with the realistic specimen of its narrated activity. As the authors of the recent scholarly volume on materiality formulated it, the "natural knowledge" became increasingly meaningful in modern societies so that it "forged new connections among groups, helped create new identities," and moreover "brought about new kinds of claims to authority and intellectual legitimacy." (Cook et al. 2014). Accordingly, it gave rise to "new ways of thinking about the senses, certainty, and epistemology." As the authors of this collection aptly summarize, none of the above could have happened without the "conversations and controversies" that permeated the assessment of objects versus their images and perceptions in various novel ways. Peppershtein's and Anufriev's epic narrative is a vivid and picturesque example that can testify to this line of thought.

\section{Bibliography}

Abdullaev, Kazim. 2009. The Cult of Haoma in Ancient Central Asia. Samarkand: IICAS, UNESCO.

Allegro, John M. 1970. The Sacred Mushroom and the Cross. New York: Doubleday.

Allen, John W. 1997. Teonanacatl: Ancient and Contemporary Shamanic Mushroom Names of Mesoamerica and Other Regions of the World. Seattle (WA): Psilly Publications, Raver Books.

Anderson, Edward. 1980. Peyote: The Divine Cactus. Tucson (AZ): University of Arizona Press.

Arthur, James. 2000. Mushrooms and Mankind: The Impact of Mushrooms on Human Consciousness and Religion. Escondido (CA): The Book Tree.

Batyanova, E.P. 2001. "Mukhomor v lechebnoi i obryadovoi praktike narodov Sibiri", Shamanizm i inye traditsionnye verovaniya i praktiki: materialy mezhdunar. kongressa.17-12 iunia 1999. Moskva: 69-81.

Batyanova, E.P. 2001a. "Muhomor kak mifologicheskij personazh narodov Krainego Severa". Hudozhestvennyi mir tradicionnoi kul'tury: Sbornik statei k 75-letiiu V.G. Smolitskogo. Moskva: $165^{-176 .}$

Batyanova, E.P., Bronshtein M.M. 2016. "Mukhomor v bytu, obryadah, iskusstve narodov Severa". Sibirskie istoricheskie issledovaniia. № 1 : 46-58. 
Belova, O.V. 1996. "Eroticheskaya simvolika gribov v narodnyh predstavleniyah slavyan", Seks i erotika v russkoi tradicionnoi kul'ture. Moskva: 317-322.

Berger, Arthur Asa. 20o9. What Objects Mean: An Introduction to Material Culture. Walnut Creek (CA): Left Coast Press.

Beug, Michael W. 2006. "The Poisonous and Hallucinogenic Mushrooms." http:// academic.evergreen.edu/projects/mushrooms/phm/s32.htm. Accessed April 29, 2015.

Bogoraz, Wladimir G. 1991. Material'naia kul'tura chukchei.105-115. Moskva: Izdatel'stvo Nauka.

Boyer, Ruth M.; Boyer, Harry W. 1973. "Shamanism and Peyote Use among the Apaches of the Mescalero Indian Reservation." In Michael J. Harner (ed.). Hallucinogens and Shamanism. 53-67. Oxford: Oxford University Press.

Brehman, Israil'; Sem, Iurii. 1970. "Etnofarmakologicheskoe issledovanie nekotorykh psihoaktivnykh sredstv malykh narodov Sibiri i Dal'nego Vostoka”. In Lekarstvennye sredstva Dal'nego Vostoka. Khabarovsk. Vyp. 10:16-19.

Brough, John. 1971. "Soma and Amanita muscaria." Bulletin of the School of Oriental and African Studies 34:331-364.

Burroughs, William; Ginsberg, Allen. 1963. The Yage Letters. San Francisco (CA): City Lights Books.

Chernin, Anton. 2006. Nasha muzyka: pervaia polnaia istoriia russkogo roka, rasskazannaia im samim. Sankt-Peterburg: Amfora.

Clark, Walter Houston. 1969. Chemical Ecstasy: Psychedelic Drugs and Religion. New York: Sheed and Ward.

Cook, Harold J.; Smith, Pamela H.; Meyers, Amy R.W. 2014. "Introduction: Making and Knowing". In Ways of Making and Knowing: The Material Culture of Empirical Knowledge. Ann Arbor (MI): The University of Michigan Press.

Cushman, Thomas. 1995. Notes from Underground: Rock Music Counterculture in Russia. Albany (NY): State University of New York Press.

Danilkin, Lev; Brashinskii, Mikhail. 2003. "Baklazhan moi. Mifogennaia Liubov' Kast.” Afisha 96. http://vozduh.afisha.ru/archive/mlk_pepper1/, accessed 01.12.2018.

Degot, Ekaterina; Zakharov Vadim. (eds.). 2005. Moscow Conceptualism. World Art Museum, Moscow. № $15^{-16}$.

Dikson, O. 2008. Misterii muhomora: primenenie halliucinogennogo griba v shamanskoi praktike. Moskva: Veligor.

Dobkin de Rios, Marlene. 1976. The Wilderness of Mind: Sacred Plants in Cross Cultural Perspective. Beverly Hills (CA): Sage Publications.

Dobkin de Rios, Marlene. 1977. "Hallucinogenic Ritual as Theatre." Journal of Psychodelic Drugs 9.3:265-268.

Dobkin de Rios, Marlene; Smith, David E. 1977. “The Function of Drug Rituals in Human Society: Continuities and Changes.” Journal of Psychodelic Drugs 9.3:269-275. 
Dobkin de Rios, Marlene. 1984. Hallucinogens: Cross-CulturalPerspectives. Albuquerque (NM): University of New Mexico Press.

Dobkin de Rios, Marlene. 1984. Visionary Vine: Hallucinogenic Healing in the Peruvian Amazon. Prospect Heights (IL): Waveland.

Du Toit, Brian M. (ed.). 1977. Drugs, Rituals and Altered States of Consciousness. Rotterdam: A.A. Balkema.

Dunn, Ethel. 1973. "Russian Use of Amanita muscaria: A Footnote to Wasson's Soma." Current Anthropology 4:488-492.

Elizarenkova, Tatiana; Toporov, Vladimir. 1970. "Mifologicheskie predstavlenija o gribakh v sviazi s gipotezoi o pervonachal'nom kharaktere somy." Tezisy dokladov IV letnej shkoly po vtorichnym modelirujushhim sistemam. 40-46. Tartu: Ülikooli.

Esanu, Octavian. 2012. Transition in Post-Soviet Art: The Collective Actions Group Before and After 1989. Budapest, New York: Central European University Press.

Estrada, Alvaro. 1981. Maria Sabina: Her Life and Chants, (Vida de Maria Sabina). Trans. Henry Munn. Santa Barbara (CA): Ross-Erikson.

Fabing, Howard D. 1956. "On Going Berserk: A Neurochemical Inquiry." Scientific Monthly 83.5:232-237.

Ford, Lisa L. 2014. "From Plant to Page: Aesthetics and Objectivity in a Nineteenth-Century Book of Trees". Ways of Making and Knowing. Pamela H. Smith, Amy R. W. Meyers, and Harold J. Cook, editors. University of Michigan Press, 221-243.

Fowler, Chris. 2010. "From Identity to Material Culture, to Personhood and Materiality". In Dan Hicks and Mary C. Beaudry (eds.). The Oxford Handbook of Material Culture Studies. $35^{2-385}$. Oxford: Oxford University Press.

Friedman Julia P. and Adam Weiner. 1999. “Between a Rock and a Hard Place: Holy Rus' and Its Alternatives in Russian Rock Music". In: Consuming Russia: Popular Culture, Sex, and Society since Gorbachev, ed. Adele Marie Barker, Duke University Press. 110-138.

Furst, Peter T. 1976. Hallucinogens and Culture. Novato: Chandler and Sharp.

Furst, Peter T. (ed.). 199o. Flesh of the Gods: The Ritual Use of Hallucinogens. Long Grove (IL): Waveland Press.

Furst, Peter T. 1992a. "Feathered Crowns of Power: Bird Symbolism in Amazonian Shamanism." In Shaman's Drum 29::40-47.

Furst, Peter T. 1992b. "The Fly Agaric in the New World". In Peter T. Furst. Mushrooms: Psychedelic Fungi, Encyclopedia of Psychoactive Drugs. London: Chelsea House.

Georgievsky, I. 2016. “Petroglyphy na skalakh vdol' Chukotskoi reki Pegtymel—samye severnye naskalnye risunki v mire". (The Pegtymel river petroglyph art). Vogrug Sveta, vol. 2. http://www.vokrugsveta.ru/article/243708/

Glanc, T. 2001. "Psikhodelicheskii realism. Poisk kanona". NLO, vol. 51. 
Gordeeva, O.V. 2017. "Psihologicheskie effekty muhomora krasnogo (Amanita muscaria)". Sibirskie istoricheskie issledovaniia. № 2: 152-183.

Groys, Boris. 2003. "Medicinskaja hermenevtika, ili lechenie ot zdorovia." In Boris Groys. Iskusstvo utopii. 240-245. Moskva: Khudozhestvennyi Zhurnal.

Groys, Boris. 2004. "Medical Hermeneutics: After the Big Tsimtsum". In Matthias Haldemann (ed.). Pavel Pepperstein und Gäste/Pavel Peppershtein and Guests. 196205. Ostfildern-Ruit, Kunsthaus Zug: Hatje Cantz Verlag.

Guilhou, Nadine. 1998. "Les deux morts d'Osiris d'après les Textes des Pyramides." In Egypte Afrique \& Orient. 19-26. Avignon: Centre vauclusien d'Égyptologie.

Harner, Michael (ed.). 1973. Hallucinogens and Shamanism. Oxford: Oxford University Press.

Heinrich, Clark. 2002. Magic Mushrooms in Religion and Alchemy. Rochester (VT): Park Street Press.

Hicks, Dan; Beaudry Mary C. (eds). 2010. The Oxford Handbook of Material Culture Studies. Oxford: Oxford University Press.

Hudler, George W. 1998. Magical Mushrooms, Mischievous Molds. Princeton (NJ): Princeton University Press.

Ioffe, Dennis. 2006. "Daniil Kharms as 'Homo Ludens': Ludic life-creation and the problem of the mask: on the role of ludism in the poet's activity". Russian Literature. Vol. 6o(3-4). 325-345.

Ioffe, Dennis. 2013a. "Surrealist Messengers of Time: Chronotopoi of Disruption in Kharms and Artaud." In Sascha Bru (ed.). Time and Temporality in European Modernism and Avant-Gardes (1900-1950). Theses and Abstracts. Leuven: KU Leuven.

Ioffe, Dennis. 2013b. "K voprosu o tekstualnosti khudozhestvennoj aktsii." In Dmitry Tokarev (ed.), Nevyrazimo Vyrazimoe: Ekhphrasis i problemy representatsii. 210-230. Moskva: Novoe literaturnoe obozrenie.

Ioffe, Dennis. 2014. "Laughter in Moscow Conceptualism: Locating Prigov's Irony within the Conceptualist Milieu." Russian Literature 76.3:339-359.

Ippolitova, Alexandra. 2008. Russkie rukopisnye travniki 17-18 vekov: Issledovanie fol'klora i etnobotaniki. Moskva: Indrik.

Janecek, Gerald. 2006. "Conceptualism in the Work of Sergej Sigej and Rea Nikonova”, Russian Literature, Vol. 59, Iss. 2-4, 469-485.

Kaplan, Reid W. 1975. "The Sacred Mushroom in Scandinavia." Man 10.1:71-79.

King, John Charles. 1970. A Christian View of the Mushroom Myth. London: Hodder \& Stoughton.

Kir'iak, Margarita A. 1998. "Griby v sjuzhetah zapadno-chukotskoi pozdnepaleoliticheskoi grafiki (pamiatniki mogil'nogo iskusstva)". In Mir drevnikh obrazov na Dal'nem Vostoke: Tikhookeanskaia arkheologiia. Vyp. 10. 105-123. Vladivostok: Izdatel'stvo DVGU. 
Klebanov, Michael. 2013. "Sergej Kuriokhin: The Performance of Laughter for the Post-Totalitarian Society of Spectacle. Russian Conceptualist Art in Rendezvous." Russian Literature 74.1/2:227-253.

Kolosova, Valeria. 20o9. Leksika i simvolika slavianskoi narodnoi botaniki: Ethnolingvisticheskii aspekt. Moskva: Indrik.

Kolosova, Valeria. 2014. "Etnobotanicheskie zametki 1-6." Leksicheskii atlas russkikh narodnykh govorov: Materialy i issledovaniia. Sankt-Peterburg: Nauka.

Krasheninnikov, Stepan. 1994. Opisanie zemli Kamchatki. Reprint izdania 1755. Sankt-Peterburg: Nauka.

Krivulin, V. Predgranich'e. Teksty 1993-1994. StPetersburg: Borei.

Kriuchkov, V. 2008. "Gribnoe mesto. Na Chukotke archeologi obnaruzhili sledy neobychnogo Homo Sapiens: Chelovek-mukhomor”. Itogi, \#45. http://www.itogi.ru/ paradox/2008/45/13413o.html

Kujawska, Monika. 2014. "Folk Biology of Slavic-Speaking Peoples". In Ingvar Svanberg; Łukasz Łuczaj (eds.). Pioneers in European Ethnobiology. Uppsala: University Library.

La Barre, Weston. 199o. "Hallucinogens and the Shamanic Origins of Religion." In Peter Furst (ed.). Flesh of the Gods: The Ritual Use of Hallucinogens. 261-278. Prospect Heights (IL): Waveland Press.

Leary, Timothy. 1998. The Politics of Ecstasy. Berkeley (CA): Ronin.

Levi-Strauss, Claude. 1970. "Les champignons dans la culture." L'Homme 10:5-16.

Lindenau, Jakob. 1983. "Opisanie narodov Sibiri (pervaia polovina XVII veka)". In Istoriko-etnograficheskie materialy o narodakh Sibiri i Severo-Vostoka. Magadan: Magadanskoe Knizhnoe Izdatel'stvo.

Lipovetsky, Mark. 2010. Charms of the Cynical Reason: Tricksters in Soviet and Post-Soviet Culture. (Cultural Revolutions: Russia in the Twentieth Century). Boston: Academic Studies Press.

Lozhkin, Vasya. 2017. "Interview”. EG/Gid po Ekaterinburgu. http://ekaterinburg-guide. ru/mestnym-zhitelyam/ekaterinburg-news/vasya-lozhkin

Luna, Luis Eduardo; Amaringo, Pablo. 1993. Ayahuasca Visions: The Religious Iconography of a Peruvian Shaman. Berkeley (CA): North Atlantic Books.

Markova, D.A. 2005. "Istoria kak skazka. Osvoenie voennogo mifa v romane Mifogennaia liubov kast”. Znanie, Ponimanie, Umenie. Vol. 2: 164-176.

McGlothlin, William. 1967. "Social and Para-Medical Aspects of Hallucinogenic Drugs". In Harold A. Abramson (ed.). The Use of LSD in Psychotherapy and Alcoholism. 3-43. New York: Bobbs-Merrill.

McKenna, Terence. 1999. Food of the Gods: The Search for the Original Tree of Knowledge. A Radical History of Plants, Drugs, and Human Evolution. London: Rider. 
Merck, Carl Heinrich. 1978. "Opisanie obychaev i obraza zhizni chukchei." In Etnograficheskie materialy severo-vostochnoi geograficheskoi ekspeditsii 1785-1795. 9-151. Magadan: Magadanskoe Knizhnoe Izdatelstvo.

Merkulova, Valentina. 1967. Ocherki po russkoi narodnoi nomenclature rastenii: Travy, griby, iagody. Moskva: Nauka.

Merkur, Dan. 2001. The Psychedelic Sacrament: Manna, Meditation, and Mystical Experience. Rochester (2001): Park Street Press.

Mickiewicz, Adam. 1865. Literatura stowiańska: wyktadana w Kolegium francuzkiem, 1798-1855. Poznań: Nakł. Księg. Jana Konstantego Żupańskiego.

Millington, Richard; Maxwell, Alexander. 2014. "Introduction. Tonics, Elixirs, and Poisons: Psychoactive Substances in Central European History and Culture." Central Europe 12.1:115-116.

Monastyrskii, Andrei. 1973. Slovar' terminov moskovskoi kontseptualnoi shkoly. Moskva: Ad Marginem.

Mukhomor. 2010. ed. Aleksandra Obukhova, Konstantin Zvezdochetov, Maria Sumnina. Vologda: Biblioteka Moskovskogo Kontseptualizma.

Munn, Henry. 1973. "The Mushrooms of Language." In Michael J. Hamer (ed.). Hallucinogens and Shamanism. 86-122. Oxford: Oxford University Press.

Naranjo, Plutarco. 1970. Ayahuasca, religión y medicina; etnobotánica. Quito: Editorial Universitaria.

Naranjo, Plutarco. 1995. "Archaeology and Psychoactive Plants." In R.E. Schultes; S. von Reis (eds.). Ethnobotany: Evolution of a Discipline. 391-399. London: Chapman and Hall.

Opler, Marvin. 1970. "Cross-Cultural Uses of Psychoactive Drugs (Ethnopsychopharmacology)." In W.G. Clark, and J. del Giudice (eds.). Principles of Psychopharmacology. 31-47. New York: Academic Press.

Osmond, Humphry. 1970. "Peyote Night". In Bernard Aaronson; Humphry Osmond (eds.). Psychedelics: The Uses and Implications of Hallucinogenic Drugs. 67-86. New York: Anchor Books.

Ott, Jonathan. 1994. Ayahuasca Analogues: Pangcean Entheogens. Kennewick (WA): Natural Products.

Ott, Jonathan; Bigwood, Jeremy. 1978. Teonanacatl: Hallucinogenic Mushrooms of North America. Seattle (WA): Madrona Pub.

Ott, Jonathan. 1986. “Carved 'Disembodied Eyes' of Teotihuacan.” In R. Gordon Wasson; Stella Kramrisch; Jonathan J. Ott; Carl A. P Ruck (eds.). Persephone's Quest: Entheogens and the Origins of Religion. 140-149. New Haven (CT): Yale University Press.

Ott, Jonathan. 1996. Pharmacotheon: Entheogenic Drugs, Their Plant Sources and History. Kennewick (WA): Natural Products. Ass. online at: https://anthrome.files. wordpress.com/2010/o6/pharmacotheon.pdf 
Peppershtein, Pavel; Anufriev, Sergei. 1999. Mifogennaia Liubov' Kast. Moskva: Ad Marginem.

Peppershtein, Pavel. 1993. "Rapport Noma-Noma." In Helmut R. Leppien (ed.), Noma, oder, Der Kreis der Moskauer Konzeptualisten: Installation. 8-17. Ostfildern: Cantz, Hamburger Kunsthalle.

Peppershtein, Pavel. 2005. "Ideologizacia neizvestnogo." In Ekaterina Degot; Vadim Zakharov (eds.), Moscow Conceptualism. World Art Museum, Moscow, № 15-16.

Peppershtein, Pavel. s/d. "Obo mne." Snob, http://snob.ru/profile/5323, accessed 07.12.2018.

Prishvin, Mikhail. 1983. Zelenyi shum: Sbornik. Moskva: Pravda.

Radin, Paul. 1970. "Report on the Mescaline Experience of Crashing Thunder." In Bernard Aaronson; Humphry Osmond (eds.). Psychedelics: The Uses and Implications of Hallucinogenic Drugs. 84-91. New York: Anchor Books.

Ramsbottom, John. 1954. Mushrooms \& Toadstools: A Study of the Activities of Fungi. London: Collins.

Reichel-Dolmatoff, Gerardo. 1972. "The Cultural Context of an Aboriginal Hallucinogen: Banisteriopsis Caapi." In Peter T. Furst (ed.). Flesh of the Gods: The Ritual Use of Hallucinogens. 84-113. London, Allen \& Unwin.

Reichel-Dolmatoff, Gerardo. 1975. The Shaman and the Jaguar: A Study of Narcotic Drugs among the Indians of Colombia. Philadelphia (PA): Temple University Press.

Riddle, John M.1992. Quid pro quo: Studies in the History of Drugs. Hampshire:Variorum. Riedlinger, Thomas J. (ed.). 199o. The Sacred Mushroom Seeker, Essays for R. Gordon Wasson. Portland: Dioscurides Press.

Ruck, Carl A.P.; Heinrich, Clark; Staples, Blaise Daniel. 2001. The Apples of Apollo: Pagan and Christian Mysteries of the Eucharist. Durham (NC): Academic Press.

Ryklin, Mikhail. 2000. "Peshki, lozhki i kresty”, (Janvar' 2000). https:/www.ng.ru/ kafedra/200o-o1-20/3_peshki.html, accessed 17 June 2020.

Sandford, Jeremy. 1973. In Search of the Magic Mushroom. London: New English Library. Schivelbusch, Wolfgang. 1992. Tastes of Paradise: A Social History of Spices, Stimulants, and Intoxicants. Trans. David Jacobson. New York: Pantheon Books.

Schultes, Richard Evans. 1970. "The Plant Kingdom and Hallucinogens, Pt. I-III." Bulletin on Narcotics, 21.3:3-16; 21.4:15-27; 22.1:25-53.

Schultes, Richard Evans. 1976. "Fly Agaric Mushrooms". In Richard Evans Schultes. Hallucinogenic Plants. 24-37. New York: Golden Press.

Schultes, Richard Evans; Hofmann, Albert; Ratsch Christian, (eds.). 2001. Plants of the Gods: Their Sacred, Healing, and Hallucinogenic Powers. Rochester: Healing Arts Press.

Shanon, Benny. 2002. "Entheogens. Reflections on Psychoactive Sacramentals." Journal of Consciousness Studies 9.4:85-94. 
Shanon, Benny. 2003. The Antipodes of the Mind: Charting the Phenomenology of the Ayahuasca Experience. Oxford: Oxford University Press.

Shapovalov, Alexander. 2001. "Magicheskij grib mukhomor. K voprosu ob ispol'zovanii psichotropnykh sredstv v shamanskoi praktike." Elektronnyj zhurnal Sibirskaia Zaimka, $\mathrm{N}^{\circ} 4$.

Smith, Huston. 200o. Cleansing the Doors of Perception: The Religious Significance of Entheogenic Plants and Chemicals. New York: Putnam.

Smith, Pamela H.; Meyers, Amy R. W.; Cook Harold J. (eds.). 2014. Ways of Making and Knowing: The Material Culture of Empirical Knowledge. Ann Arbor (MI): The University of Michigan Press.

Soloukhin, Vladimir. 1986. Tretia Okhota: Sozertzanie chuda. Moskva: Sovremennik.

Solzhenitsyn, Alexander. 2008. Krasnoe Koleso: Mart semnadtsatogo. Moskva: Vremia.

Spess, David. 200o. SOMA: The Devine Hallucinogen. Rochester: Park Street Press.

Spooner, Brian; Henrici, Alick; Ainsworth, Anthony Martyn. 2015. "Geastrum britannicum-A Surprisingly Common New Species in Britain." Field Mycology 16.2:54-57.

Stamets, Paul. 1978. Psilocybe Mushrooms and Their Allies. Berkeley (CA).

Svanberg Ingvar; Łuczaj, Łukasz. 2014. "Activity Contexts and Biocultural Domains.” In Pioneers in European Ethnobiology. Uppsala: University Library.

Toporov, Vladimir N. 1979. "Semantika mifologicheskih predstavlenij o gribakh." In Vladimir N. Toporov. Balcanica: Lingvisticheskie issledovaniia. 232-299. Moskva: IaRK.

Valdes, L.J.; Hatfield, G.M.; Koreeda, M.; Paul, A.G. 1987. "Studies of Salvia divinorum (Lamiaceae), an Hallucinogenic Mint from the Sierra Mazateca in Oaxaca, Central Mexico." Economic Botany 41.2:283-291.

Vekhova, T. 2019. 'Mysl' Kabakova vsegda vo mnogom stroilas' kak barochnaya. Peppershtein o Kabakove, Initsiatsii, Angelakh, Vratakh Zakona, i sgorevshem zamke". Colta.Ru. https://www.colta.ru/articles/art/20941-mysl-kabakova-vsegda -vo-mnogom-stroilas-kak-barochnaya

Vereschaka, Elena A. 2014. "Tradiciia ispol'zovaniia krasnogo mukhomora. Po etnograficheskim materialam chukchei, koriakov, itel'menov." In V.N. Davydov, D.V. Arzjutov (eds.). Sibirskij sbornik 4: Grani social'nogo: Antropologicheskie perspektivy issledovanija social'nyh otnoshenij i kul'tury. Sankt-Peterburg: MAJe RAN.

Waser, P.G. 1968. "The Pharmacology of Amanita muscaria." Psychopharmacology Bulletin 4.3:19-20.

Wasson, Valentina Pavlovna; Wasson, R. Gordon. 1957. Mushrooms, Russia and History. New York: Pantheon Books. 
Wasson, R. Gordon. 1961. "The Hallucinogenic Fungi of Mexico: An Inquiry into the Origins of the Religious Idea among Primitive Peoples." Harvard Botanical Museum Leaflets, Harvard University 19.7:137-162. http://www.maps.org/ research-archive/psychedelicreview/vin1/o1127was.pdf, accessed 17 June 2020.

Wasson, R. Gordon. 1967. "Fly Agaric and Man." In Daniel H. Efron; Bo Holmstedt; Nathan S. Kline (eds.). Ethnopharmacologic Search for Psychoactive Drugs. 405-414. Washington, D.C.: Government Printing Office.

Wasson, R. Gordon. 1971. Soma: The Divine Mushroom of Immortality. New York: Harcourt Brace Jovanovich.

Wasson, R. Gordon (ed. et. al.). 1974. Maria Sabina and Her Mazatec Mushroom Velada. New York: Harcourt Brace Jovanovich.

Wasson, R. Gordon; Ruck, Carl A.P.; Hofmann, Albert (eds.). 1978. The Road to Eleusis: Unveiling the Secret of the Mysteries. New York: Harcourt Brace Jovanovich.

Wasson, R. Gordon. 1979. "Traditional Use in North America of Amanita muscaria for Divinatory Purposes." Journal of Psychedelic Drugs 11.1/2:24-29.

Wasson, R. Gordon. 1980. The Wondrous Mushroom, Mycolatry in Mesoamerica. Ethnomycological Studies. New York: McGraw-Hill.

Wasson, R. Gordon; Kramrisch, Stella; Ruck, Carl; Ott, Jonathan (eds.). 1986. Persephone's Quest: Entheogens and the Origins of Religion. New Haven (CT): Yale University Press.

Weiss, Gerald. 1973. "Shamanism and Priesthood in Light of the Campa Ayahuasca Ceremony." In Michael J. Harner (ed.). Hallucinogens and Shamanism. 39-48. Oxford: Oxford University Press.

Wells, Herbert. 1966. The Complete Short Stories of H.G. Wells. London: Benn.

Wenzl, Katharina. 2012. Moskovskii dnevnik: 1994-1997. Moskva: Novoe literaturnoe obozrenie.

Wiegrefe, Klaus von; Altenhöner, Florian. 2007. Lenin und der Kaiser, Spiegel Special Geschichte, (4/2007). (18.12.2007) http://www.spiegel.de/spiegel/spiegelspecial geschichte/d-54841257.html

Wilcox, Joan Parisi. 2003. Ayahuasca: The Visionary and Healing Powers of the Vine of the Soul. Rochester: Park Street Press.

Yoffe, Mark. 2013. "The Stiob of Ages: Carnivalesque Traditions in Soviet Rock and Related Counterculture." Russian Literature 74.1/2:207-225.

Yurchak, Alexei. 2006. Everything Was Forever, Until It Was No More: The Last Soviet Generation. Princeton (NJ): Princeton University Press.

Yurchak, Alexei. 2011. "A Parasite from Outer Space: How Sergei Kuryokhin Proved that Lenin Was a Mushroom." Slavic Review 70.2:307-332. 
Yurchak, Alexei. 2013. "Netlennost' formy: Leninism i materialnost' mavzoleinogo tela." Neprikosnovennyi zakaz 3 (89).

Yurchak, Alexei. 2015. "Bodies of Lenin: The Hidden Science of Communist Sovereignty." Representations 129.

Zinberg, Norman E. 1984. Drug, Set and Setting: The Basis for Controlled Intoxication Use. New Haven (CT) and London: Yale University Press. 